\title{
Fund Family Tournament and Performance Consequences: Evidence from the UK Fund Industry
}

\author{
Zhichao Zhang \\ Durham University, UK \\ Li Ding \\ Durham University, UK \\ Si Zhou* \\ University of Southampton, UK \\ Yaoyao Fu \\ Durham University, $U K$
}

\begin{abstract}
By applying tournament analysis to the UK Unit Trusts data, the results support significant risk shifting in the family tournament; i.e. interim winning managers tend to increase their level of risk exposure more than losing managers. It also shows that the risk-adjusted returns of the winners outperform those of the losers following the risk taking, which implies that risk altering can be regarded as an indication of managers' superior ability. However, the tournament behaviour can still be a costly strategy for investors, since winners can be seen to beat losers in the observed returns due to the deterioration in the performance of their major portfolio holdings. (JEL: G20, G23)
\end{abstract}

Keywords: mutual fund family; fund performance; tournament; risk taking

\section{Introduction}

Most mutual funds belong to a fund family. Several previous studies

* Corresponding author. Postal address: Southampton Business School, Building 2, Highfield Campus, University of Southampton, Southampton, SO17 1BJ, UK. E-mail: s.zhou@soton.ac.uk.

(Multinational Finance Journal, 2014, vol. 18, no. 1/2, pp. 43-84)

(C) Multinational Finance Society, a nonprofit corporation. All rights reserved. DOI: $10.17578 / 18-1 / 2-2$ 
examine the characteristics of these fund families. Guedj and Papastaikoudi (2003), and Massa (2003) analyse how performance of the individual fund can be affected by its affiliated family. Nanda et al. (2004) discuss the close relation between the growth of cash inflows of a certain fund and the superior performance of other peer funds within the same family. Gaspar et al. (2006) study how a fund family allocates resources to promote the funds which have the potential to improve the profits of the entire fund family. However, previous research devotes little attention to the relation between the behaviour of individual funds and other peer funds within the same family. Kempf and Ruenzi (2008) (KR hereafter) are the first to examine such a connection. They consider the fund tournament phenomenon in the fund family, first reported in Brown et al. (1996). Despite their findings of differential levels of risk exposure for winners and losers, it remains debatable whether the risk taking behaviour stimulated by the fund tournament benefits the fund performance and the overall profits of the fund family. One also wonders whether the risk taking behaviour is a consequence of the agency problem, or just an indication of managers' inferior ability.

Mutual funds alter their risk exposure frequently for various reasons. Chevalier and Ellison (1997) and Sirri and Tufano (1998) find a convex relation between the funds' previous performance and changes of their cash inflows. Underperforming funds may therefore take more risks to bet on better performance given the disproportionate response from cash flows to previous fund performance. Underperforming funds may also alter the level of portfolio risk before the reporting date to manipulate their performance record Goetzmann et al., 2007; Lakonishok et al., 1991), or to conduct asset allocation strategies to promote certain investment style (Faff et al., 2012). On the other hand, funds may use risk shifting to indicate active trading or superior stock selection ability, which may not necessarily indent investors' benefits Kacperczyk et al. (2005). Managers are also compelled to work for the interest of the whole family. In the context of a fund family, funds gain resources and information advantages from the family by winning the competition. Also, it is the fund family that decides which managers are to be promoted or demoted based on the tournament outcome. As a result, managers should change their risk exposure only to improve the fund performance, rather than increase the overall uncertainty of the family. However, to date there has been little research on the relation between risk altering and performance shifting.

This research is the first to discuss performance shifting in relation to the risk taking in the family tournament. Using data from the UK unit 
trust industry, the results show that funds with better previous performance actively participate in the family tournaments by increasing their risk exposure in the second half of the calendar year, while the opposite is true in the segment tournament. The results persist when funds are ranked by risk-adjusted performance. This paper also documents a positive relation between family ranks and future risk taking in bear market condition. Namely, mid-year winners increase their risk level higher than the losers since the losing managers are concerned more about their jobs. The performance consequences conducted in this research show that the interim winners can outperform the losing ones in risk adjusted returns by taking more risk, whereas the opposite is true when turning to the observed returns. The decreasing observed returns in the winning group is probably due to the return deteriorations from increased holdings of high beta stocks.

This research fill the gap of literature on UK fund family tournament as well as the empirical analysis on the performance consequences to the tournament behaviour. It is argued that interim winners might value the importance of employment concerns and family favouritism more seriously than the losers, which might urge their risk increasing to secure the leading position, and also they aim to signal the fund family of their superior ability with high fund alphas in order to gain more resource from the family.

While the findings about the family tournament differ than those in KR, they are consistent with those of Mas-Colell et al. (1995). Specifically, the winning funds in a small fund group are more likely to engage in a tournament with strategic interactions. The cut-off points by KR to identify large and small families in the US fund industry are 16, 21,31 and 36 funds, whereas in the UK the average family size is 4 , and the largest family consists of only 11 funds. Thus, the entire sample of fund families can be classified as small families in the KR sense. Second, the results confirm the effects of employment concerns in relation to fund risk taking. Extant research suggests that, despite the compensation schemes that are based on asset values, fund managers are also exposed to employment risk, as they need to keep their jobs. Taking more risk provides a means for the losing managers to bet on better performance, though it may also raise the probability of performing even worse. Relative to the losing managers, the interim winners are under less employment pressure. Therefore, the underperforming managers tend to take less risk than good performers (Chevalier and Ellison, 1997; Kempf et al. 2009). Third, and most important, the 
analysis of performance consequences shows that risk taking can serve as an indication of managers' superior stock selection ability. It also acts as a crucial criterion for the fund family to decide which fund should be advertised or favoured with extra resources. Thus, it stands to reason that winner funds would actively consider shifting risk exposure to retain their leading positions. The current research unearths significant empirical evidence of changes in the risk taking behaviour in the family tournaments. The results also support the conclusion that risk taking helps top performing managers win the competition.

This paper is organized as follows. The next section summarizes the related literature. Section III describes the empirical methods to be implemented in this research, while section IV discusses the data and presents the descriptive statistics of the datasets. Section V reports the empirical findings from the tournament analysis, and the performance consequences due to tournament related risk taking. The results are then summarized in the final section.

\section{Related literature}

This research relates to three strands of literature. First, it revisits the tournament phenomenon presented by many fund tournament studies. Brown et al. (1996) (BHS hereafter) are among the first to document the evidence that managers from half-year-losing funds have incentives to alter their risk exposure more significantly than those from the half-year-winning funds. They report that half-year losers are more likely to increase their exposure to portfolio risk for the second half of the calendar year in an attempt to improve their future position against peer funds, while half-year winners tend to decrease risk exposure to retain their leading position. The motivation behind such tournament behaviour can be explained by the disproportionate amount of capital injected into top performing funds relative to the underperforming funds (Chevalier and Ellison, 1997; Sirri and Tufano, 1998). Using monthly data and contingent tables, Jans and Otten (2008) find significant evidence that mid-year losers increase risk exposure more than mid-year winners in the first sub period, 1989-1996, of their sample using the UK unit trust data. But the risk shifting behaviour reverses in the rest of their sample period, 1997-2003, as they argue that a strategic game is conducted by both the winners and the losers; i.e., both parties might alter their risk shifting based on the decision made by the opposite 
parties. In recent research, Kempf et al. (2009) and Schwarz (2011) apply the portfolio holding data in the tournament analysis. They argue that, compared with estimating the realized risk, deploying the portfolio holding data to estimate volatility better represents the managers' intention to alter the exposure to portfolio risk. However, holding data might not be sufficient to address managers' frequent risk shifting, since funds might only publish their holding data on a quarterly basis or even on a half-year basis.

The second strand of literature relevant to this research is the fund family literature. Fund families play an important role in funds operation. Since individual funds are usually affiliated to different fund complexes, it is the fund family that decides managers' promotion or demotion, and which funds to market (Jain and $\mathrm{Wu}, 2000$ ). Fund companies also conduct various types of strategies to enhance the performance of certain funds, such as undertaking cross-fund subsidization to promote funds with high past performance through allocating new IPO shares (Gaspar et al., 2006). On the other hand, fund companies also have the motivation to support family tournament. Nanda et al. (2004) suggest that the growing cash inflows attracted by families with star funds can bring new capital not only to the star funds, but to other funds within the same family, i.e. the spillover effect. They also find evidence that star families tend to increase the volatility of cross-sectional returns in order to increase the odds of creating star funds. In other words, risk taking in family tournament is a reasonable strategy, from which a fund company can benefit greatly.

The third strand of literature to which this research is related is the growing field of funds' risk taking. There are a large number of studies discussing the purposes of funds' risk shifting. Most of the studies identify that risk shifting is a major channel for the managers to promote cash inflows (See Chevalier and Ellison, 1997; Sirri and Tufano, 1998). Huang et al (2011) (HSZ hereafter) initiate the discussion on the performance consequences of risk shifting. Using portfolio holding data of the US mutual fund industry, they find that funds with stable risk levels provide better performance than funds significantly altering their risk levels. As it is costly for the fund investors to bear the loss of funds during risk shifting, they argue that such behaviour is merely an indication of inferior ability or due to compensation concerns. However, despite a large number of studies examining the tournament behaviour and the risk shifting in the fund industry, few studies have followed the HSZ model to conduct a complete analysis of the performance 
consequences of family tournament. Our research is therefore set to fill the gap from an empirical perspective.

\section{Methodology}

To identify the risk taking behaviour in the family tournament, an empirical model suggested by KR is adapted as follows:

$$
\begin{aligned}
\Delta \sigma_{i, t}= & \alpha_{i}+\beta_{i}^{(1)} R_{i, t}^{\text {Fam }} D_{l}+\beta_{i}^{(2)} R_{i, t}^{\text {Fam }} D_{s}+\beta_{i}^{(3)} R_{i, t}^{S e g} D_{l}+ \\
& \beta_{i}^{(4)} R_{i, t}^{\text {Seg }} D_{s}+\beta_{i}^{(5)} \sigma_{i, t-1}+\beta_{i}^{(6)} \Delta \sigma_{m e d}+\varepsilon_{i, t}
\end{aligned}
$$

where $\Delta \sigma_{i, t}$ is the difference of funds' volatility between the ranking period and the post-ranking period. Different measures are conducted in examining the volatility shifting, including the total risk, the systematic risk and idiosyncratic risk. Volatility difference of the entire family is also calculated, to analyse whether tournament behaviour might occur at the family level. A fund family's overall risk level is based on the value weighted returns of all funds within the same family. Previous studies consider the tournament behaviour on an annual basis, in which the ranking period lasts from 6 to 8 months (e.g. BHS; Jans and Otten, 2008). KR consider only the 7-month ranking period. To fully address the time frame issue of the tournament behaviour, our investigation includes the cases with both the June 6-month ranking period) and July 7-month ranking period) cut-off points, while also considering the quarter-ranking period to further the analysis of managers' risk shifting strategy. In equation 1$), R_{i, t}^{F A M}$ and $R_{i, t}^{\text {Seg }}$ are the family rank and segment rank, respectively. The segment rank is generated by arranging funds of the same segment in ascending order according to their performance in the ranking period. All sampled funds are classified into three segments according to the IMA category of investment styles, i.e. UK All Companies, UK Equity Income and UK Smaller Companies.

For measuring the performance, BHS and KR use funds' raw returns only, due to the fact that the raw returns are the major concern of investors. Given the recent concern that the close connection between risk and returns might bias the tournament analysis (Schwarz, 2012), Jensen alphas is also considered as a measure of the risk-adjusted 
performance. In order to make ranks from different investment styles comparable, we normalize the rank by using the function $\left(R_{i}-1\right) /\left(N_{i}\right.$ -1 ), where $R_{i}$ is the segment rank of fund $\mathrm{i}$ and $N_{i}$ is the size of the corresponding segment. The family rank is calculated by further ranking the normalized segment rank from funds within the same family in ascending order. Thus, the family rank measures the relative performance of each member in the family. We also normalize the family rank using the same method, with $N_{i}$ being the size of the corresponding family. $D_{i}\left(D_{s}\right)$ is the dummy variable that represents a large (small) fund family. Two criteria is therefore considered to classify fund family into large and small, namely, the aggregate value of the family and the family size. This is because some of the families may have only a limited number of members, but each member has a large size of underlying assets. The model also includes the funds' volatility in the ranking period, $\sigma_{i, t-1}$, and the median difference of funds' risk in each of the segments, $\Delta \sigma_{\text {med }}$, to capture the exogenous factors that lead to risk shifting.

For the performance consequences of family tournament, the performance differences is applied to examine the performance shifting of individual funds. An empirical model is then constructed to analyse how performance changes from the family perspective can be explained by changes in the risk taking behaviour. Given that funds participate in the tournament to win the competition, it is the relative performance rather than the absolute performance that matters to the managers. Thus, link can be built with the risk taking behaviour to the rank changes of a certain fund. With the spillover effect and disproportionate relation between historical performance and cash inflows, fund families also have incentives to take on higher risk exposure in family tournament. The empirical model can be formulated as follows:

$$
\begin{aligned}
R_{i, t}^{\text {Family }}= & \alpha_{i}+b_{i}^{(1)} R_{i, t}^{\Delta \sigma}+b_{i}^{(2)} \Delta \Lambda_{i, t}^{\sigma} D_{\text {Star }}+b_{i}^{(3)} \Delta \Lambda_{i, t}^{\sigma} D_{\text {Dog }}+ \\
& b_{i}^{(4)} \Delta \Lambda_{i, t}^{\sigma} D_{\text {Star }, \text { Dog }}+b_{i}^{(5)} \Delta \Lambda_{i, t}^{\beta} D_{\text {Star }}+b_{i}^{(6)} \Delta \Lambda_{i, t}^{\beta} D_{\text {Dog }}+ \\
& b_{i}^{(7)} \Delta \Lambda_{i, t}^{\beta} D_{\text {Star }, \text { Dog }}+b_{i}^{(8)} \Delta \Lambda_{i, t}^{\epsilon} D_{\text {Star }}+b_{i}^{(9)} \Delta \Lambda_{i, t}^{\epsilon} D_{\text {Dog }}+ \\
& b_{i}^{(10)} \Delta \Lambda_{i, t}^{\epsilon} D_{\text {Star }, \text { Dog }}+\epsilon_{i, t}
\end{aligned}
$$

where $R_{i, t}^{\text {Family }}$ is now the overall family rank of family $i$ in the 
post-ranking period. ${ }^{1}$ A high $R_{i, t}^{\text {Family }}$ indicates that the funds within the family experience a positive performance shift with a smaller cost of funds being demoted. $R_{i, t}^{\Delta \sigma}$ measures the level of risk shifting in a certain family. A similar aggregate ranking ratio is generated for each family according to the changes in the level of risk exposure of the underlying funds. $\Delta \Lambda_{i}^{\sigma}, \Delta \Lambda_{i}^{\beta}$ and $\Delta \Lambda_{i}^{\varepsilon}$ measure the cross-sectional differences in the total risk, systematic risk and idiosyncratic risk, respectively. $\mathrm{D}_{\text {Star }}$ is equal to $1(0)$, if the family that fund $i$ is affiliated to is a star (dog) family. A star family contains at least one fund ranked in the top quartile of the segment star fund) in the ranking period, while a dog family includes any bottom performing funds dog fund). $D_{\text {Star,Dog }}$ denotes a family that has both star and dog funds in the ranking period. Both star and dog families may have motivation to promote family tournament; i.e. the dog family will seek to improve the performance of its dog fund by betting on the market, while the star family tends to retain the position of the star funds in its group. Further, fund families also have the ability to promote the tournament behaviour by resource reallocation, i.e. family favouritism and the spillover effect. Thus, by sorting families into star and dog types, it is able to explore which types of families are more likely to be involved in the tournament. Additionally, we may discover how performance of the peer funds in a star/dog family responds to the tournament behaviour.

\section{Data}

The funds' raw data are obtained from Morningstar. We collect daily total returns data for the UK unit trust industry during the period between 2001 and 2010. The funds selected into the sample are all UK domiciled, equity based unit trusts and OEICs. ${ }^{2} \mathrm{We}$ exclude funds

1. The family rank is worked out by first taking the difference in the segment rank of each sampled fund between the ranking and post-ranking period. Then we further rank each of the fund families using the aggregate ranking ratio. For example, if family $i$ has three funds, $A, B$ and $C$, the differences in normalized segment rank for each fund are $A=0.1, B=0$ and $\mathrm{C}=-0.3$. Here, $\mathrm{A}=0.1$ means that fund $A$ improves its ranking ratio by 0.1 ; fund $\mathrm{C}$ has been demoted by 0.3 in the segment rank and fund $B$ has no change in its rank. The aggregate ranking ratio for family $i$ thus equals to $-0.3+0+0.1=-0.2$.

2. Unit trusts and OEIC s are both open-ended investments with different bid/ask pricing, legal structures and up-front loads. However in practice, they can both be regarded as mutual fund equivalents. 
targeting fixed income securities and mixed investments; the index linked funds are also taken out of the sample. The sampled funds belong to 3 IMA sectors: UK All Companies, UK Equity Income and UK Small Companies. We treat these 3 IMA sectors as the 3 largest segments in our tournament analysis. With regard to fund families, this research regards a fund family as being formed by the funds that are managed by the same fund company. For each of the families, we only keep the oldest fund in the same share class, since funds within the same share class deliver similar rates of returns. ${ }^{3}$

Table 1 reports the summary statistics for the sample funds in this research. It shows a rapid growth of the UK fund industry, although the population of UK funds is still moderate in numbers compared to the US fund industry. Both the number of funds and the number of fund families increased dramatically in the sample period. There were only 159 UK domiciled equity funds in 2001, and this number had doubled to 324 by 2010 , particularly the year of 2010 also sees the significant growth of funds within the UK all companies sector. Columns 3 and 4 report the mean cross-sectional returns and standard deviations of the sample funds. In general, a weak association is recognized between higher levels of risk and higher observed returns among the fund population, but exceptions occur in 2001/2002 and 2007/2008, when the market suffered from the dot-com bubble and the global financial crisis, respectively.

Apart from the raw returns, Jensen alphas are also estimated as a measure of the funds' risk-adjusted performance. Three sets of benchmark returns are employed to proxy the excessive market returns (MKT), the size effect (SMB), the book to market effect (HML) and the momentum effect (UMD). We choose the FTSE All Shares index as the basis for calculating market returns, and hence the MKT. Use of the MKT factor is motivated by the conventional CAPM model. The HML and SMB factors are adopted following the Fama-French 3-factor model, and computed by two pairs of market portfolios. SMB is generated by taking the difference between the FTSE 100 index and the FTSE small capital index; HML is calculated by taking the difference between the MSCI UK Growth index and MSCI UK Value index

3. The oldest fund is normally the first fund established by the fund company in the share class. Other peer funds within the same share class can be created individually or by splitting from the oldest one, but they all share a management team and a similar portfolio composition. Morningstar provides additional information indicating the oldest fund from the same share class. 


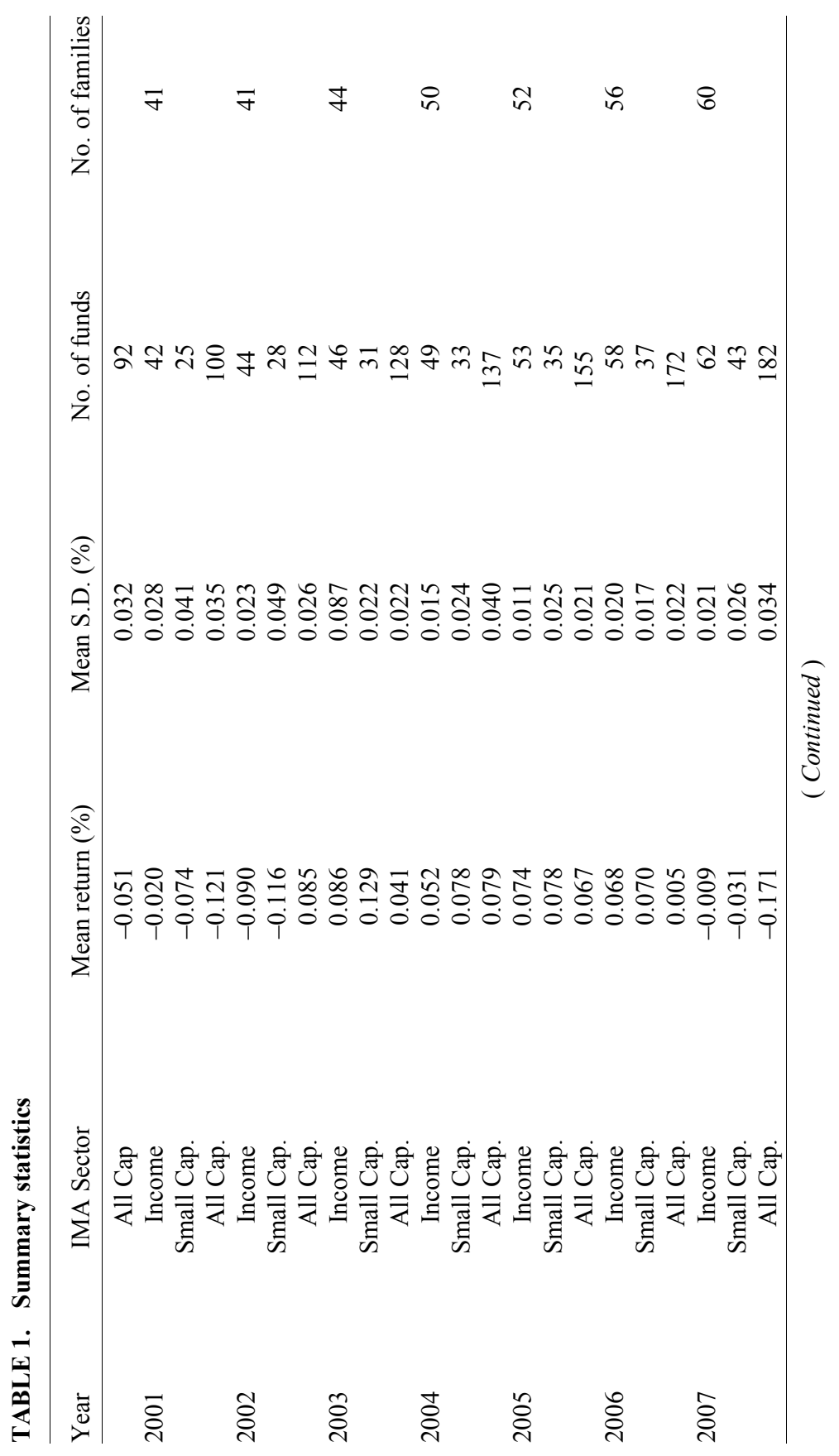




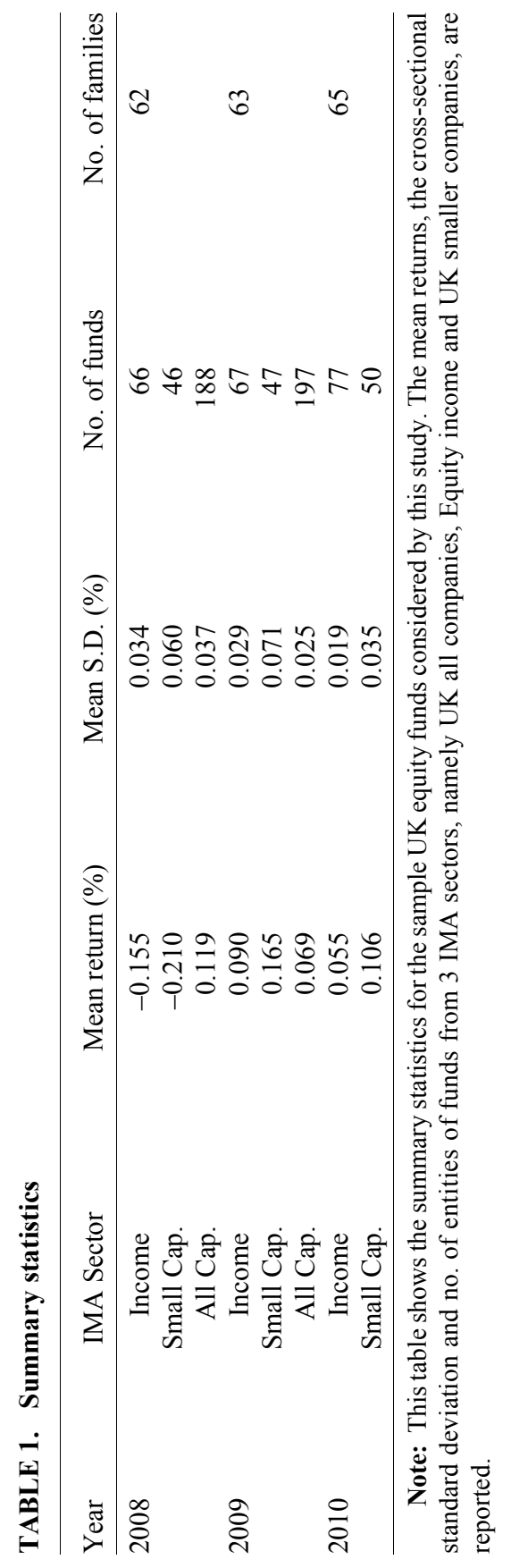


suggested by Cuthbertson et al. (2008). Following the method presented in French's website, the UMD factor in the Carhart 4-factor model is generated by extracting the returns of the 1-year low return portfolio from the returns of the 1-year high return portfolio. ${ }^{4}$

\section{Empirical results}

\section{A. Risk taking in the segment and family tournaments}

Table 2 reports the regression results fitting by model (1). In general, it shows significant evidence of funds engaging in both family and segment tournaments. In column 2 of Panel A, when the half-year ranking period is considered, the main indicator of family tournament, $R_{i, t}^{\text {Fam }}$, has a significant and positive coefficient on the large-value-family dummy, although no significant tournament behaviour is found in small families. The segment tournament indicator, $R_{i, t}^{S e g}$, has a significantly negative factor loading on either the large or the small family dummy variable. The positive coefficient on $R_{i, t}^{\text {Fam }} \cdot D_{i}^{V}$ indicates that top ranking funds in the large families take more risk than bottom ranked ones, which is consistent with the theoretical prediction of strategic tournament by Taylor (2003). This result is also consistent when the cut-off point of the ranking period turns to be 7 months in the second column of Panel A.

The negative coefficient on $R_{i, t}^{\text {Seg }}$ suggests a non-strategic segment tournament in which half-year underperforming funds are more likely to increase their risk exposure in the second half of the year than are the top performing ones. The risk shifting behaviour in segment tournament is more sensitive in small families than in large ones by more than 50 basis points.

Our findings regarding the family tournament are contrary to those reported in $\mathrm{KR}$, which suggests that underperforming funds within a small family increase risk more than over-performing ones. Our results however do indicate that managers of the mid-year winners choose to increase their risk exposure than the mid-year losers. This is particularly true for those from the large sized families, since large sized funds have more capital to fund strategy shifting or are the market makers that

4. The detailed method of calculating the moment factor can be found in French's website, http://mba.tuck.dartmouth.edu/pages/faculty/ken.french/data_library.html. 
TABLE 2. Family and segment tournaments

A.

\begin{tabular}{llclll} 
& $(6,6)$ & $(7,5)$ & $(\mathrm{Q} 1, \mathrm{Q} 2)$ & $(\mathrm{Q} 2, \mathrm{Q} 3)$ & $(\mathrm{Q} 3, \mathrm{Q} 4)$ \\
\hline$R_{i, t}^{\text {Fam }} \cdot D_{I}^{V}$ & $0.0050^{* *}$ & $0.0049^{* *}$ & $0.0040^{* *}$ & $0.0045^{* *}$ & $0.0065^{* *}$ \\
$R_{i, t}^{\text {Fam }} \cdot D_{s}^{V}$ & 0.0033 & $0.0018^{* * *}$ & 0.0020 & -0.0019 & 0.0040 \\
$R_{i, t}^{\text {Seg }} \cdot D_{I}^{V}$ & $-0.0076^{* * *}$ & $-0.0068^{* * *}$ & 0.0037 & $-0.0104^{* * *}$ & $-0.0076^{* *}$ \\
$R_{i, t}^{\text {Seg }} \cdot D_{s}^{V}$ & $-0.0127^{* * *}$ & $-0.0074^{* * *}$ & 0.00002 & $-0.0091^{* * *}$ & $-0.0111^{* * *}$ \\
$\sigma_{i, t}-1$ & $-3.5697^{* * *}$ & $-2.9213^{* * *}$ & $-4.8218^{* * *}$ & $-4.0134^{* * *}$ & $-3.6620^{* * *}$ \\
$\Delta \sigma_{\text {med }}$ & $13.6588^{* * *}$ & $12.9068^{* * *}$ & $7.0209^{* * *}$ & $14.3347^{* * *}$ & $11.8634^{* * *}$ \\
$R^{2}$ & $88.35 \%$ & $89.12 \%$ & $74.18 \%$ & $86.61 \%$ & $83.15 \%$ \\
\hline
\end{tabular}

B.

\begin{tabular}{llllll} 
& $(6,6)$ & $(7,5)$ & $(\mathrm{Q} 1, \mathrm{Q} 2)$ & $(\mathrm{Q} 2, \mathrm{Q} 3)$ & $(\mathrm{Q} 3, \mathrm{Q} 4)$ \\
\hline$R_{i, t}^{\text {Fam }} \cdot D_{I}^{S}$ & $0.0054^{* *}$ & 0.0034 & $0.0076^{* * *}$ & 0.0031 & $0.0067^{* *}$ \\
$R_{i, t}^{\text {Fam }} \cdot D_{s}^{S}$ & 0.0028 & 0.0033 & 0.0023 & 0.0003 & 0.0041 \\
$R_{i, t}^{\text {Seg }} \cdot D_{I}^{S}$ & $-0.0105^{* * *}$ & $-0.0061^{* *}$ & -0.0007 & $-0.0091^{* * *}$ & $-0.0097^{* * *}$ \\
$R_{i, t}^{\text {Seg }} \cdot D_{s}^{S}$ & $-0.0115^{* * *}$ & $-0.0098^{* * *}$ & 0.0036 & $-0.0111^{* * *}$ & $-0.0095^{* * *}$ \\
$\sigma_{i, t}-1$ & $-3.5662^{* * * *}$ & $-2.9171^{* * *}$ & $-4.8229^{* * *}$ & $-4.0229 * * *$ & $-3.6757^{* * *}$ \\
$\Delta \sigma_{\text {med }}$ & $13.6754^{* * *}$ & $12.9184 * * *$ & $7.0462^{* * *}$ & $14.3398 * * *$ & $11.8655^{* * *}$ \\
$R^{2}$ & $88.34 \%$ & $89.13 \%$ & $74.23 \%$ & $86.58 \%$ & $83.12 \%$ \\
\hline
\end{tabular}

Note: This table presents the regression results from the family tournament model (1). $R_{i, t}^{F a m}$ and $R_{i, t}^{\text {Seg }}$ are the family and segment ranks based on the funds' daily total returns, respectively. $D_{1}\left(D_{s}\right)$ is the dummy variable which equals to $1(0)$ when fund $i$ belongs to a large (small) fund family. $\sigma_{i, t}-1$ indicates the risk level that fund $i$ is exposed to in the ranking period and $\Delta \sigma_{\text {med }}$ is the median difference of the segment volatility. Funds' daily returns from 3 UK IMA segments, i.e. UK All Companies, UK Equity Income and UK Small Companies, are examined for the sample years between 2001 and 2010. Panel A reports the results when fund families are sorted by funds' aggregate market size, while in Panel B results are sorted by the number of funds in a family. Column 1 presents the results when 6 months is taken as the ranking period and column 2 shows the results when the ranking period is 7 months and post-ranking period is 5 months. Columns $4-6$ report the results when a quarterly tournament is considered. All the results are based on a time fixed panel regression. $* * *, * *$ and $*$ indicate significance at the $1 \%, 5 \%$ and $10 \%$ level.

enjoy some competitive edge over the small funds.

Chevalier and Ellison (1997) argue that top performing managers may increase their risk level to retain their leading positions. In the segment tournament, mid-year winners are less motivated to compete with peer funds within the same segments, as the only reward for the winner is the new cash inflows. Existing research however shows no supportive evidence of performance improvement over the peer losers 
after the risk shifting, implying that it actually becomes even harder to attract new cash inflows by increasing risk exposure see for example (HSZ).

Mid-year winners are highly motivated in the family tournament since the winner of the tournament may be rewarded by the fund company through various forms of family favouritism. Even those mid-year winners who have already been rewarded by the family may seek for continuation of such favouritism (Guedj and Papstaikoudi, 2003; Nanda et al., 2004 and Gaspar et al., 2006). Large sized families may also encourage their member funds, particularly the winning ones, to participate in the tournament, since the winner funds could spare their new capital to benefit the other peer funds in the family. Compared with large sized families, smaller ones have no competitive edge in shifting investment strategies. Columns 4-6 of Panel A in table 2 report the outcome of the research that is extended to include the tournament analysis on a quarterly basis. The family tournament behaviour is consistently significant throughout the quarterly analysis, while segment tournament behaviour disappears between the first and second quarter.

In Panel B of table 2, the fund families are classified into large or small according to the number of their underlying family members. The results in general agree with those given in Panel A. Funds in small sized families are not actively involved in family tournament. An additional reason for this could be that funds in the families with fewer members are normally managed by the same manager or have a similar portfolio composition, which leads them to be even less motivated to engage in a family tournament.

The results from the segment tournament given by table 2 present a negative relation between the segment ranking and risk shifting, that is, loses increase their second half-year risk more than the winners. Since each of the segment contain a large group of funds, we expect the existence of non-strategic interaction in the tournament which is showed by Taylor (2003) that winners take no consideration of losers' strategies. Hence, our results are also consistent with the findings given by BHS, Koski and Pontiff (1999) and Elton et al. (2003).

To further analyse family tournaments we re-rank the funds according to their risk-adjusted returns in the ranking period, since the previous literature suggests that a close relation between risk and returns could jeopardize the tournament analysis. The risk-adjusted returns can be estimated by using the Carhart 4 factor model.

Table 3 reports the results from model (1) based on using the Jensen 
TABLE 3. Family and segment tournaments (4 Factor Model Alpha)

A.

\begin{tabular}{llllll} 
& $(6,6)$ & $(7,5)$ & $(\mathrm{Q} 1, \mathrm{Q} 2)$ & $(\mathrm{Q} 2, \mathrm{Q} 3)$ & $(\mathrm{Q} 3, \mathrm{Q} 4)$ \\
\hline$R_{i, t}^{\mathrm{Fam}} \cdot D_{I}^{V}$ & $0.0058^{* *}$ & $0.0049 * *$ & 0.0029 & $0.004 *$ & 0.0037 \\
$R_{i, t}^{\text {Fam }} \cdot D_{s}^{V}$ & 0.0022 & 0.002 & $0.0053^{* * *}$ & -0.0013 & $0.0048^{* *}$ \\
$R_{i, t}^{\text {Seg }} \cdot D_{I}^{V}$ & 0.0005 & 0.0028 & -0.0017 & 0.0016 & $-0.0059^{* *}$ \\
$R_{i, t}^{\text {Seg }} \cdot D_{s}^{V}$ & -0.002 & 0.0026 & $-0.0069^{* * *}$ & -0.0011 & $-0.0091 * * *$ \\
$\sigma_{i, t}-1$ & $-3.5048^{* * *}$ & $-2.9170^{* * *}$ & $-4.8114 * * *$ & $-3.8839 * * *$ & $-3.6208^{* * *}$ \\
$\Delta \sigma_{\text {med }}$ & $3.6334 * * *$ & $12.8792^{* * *}$ & $7.05774 * * *$ & $14.2787 * * *$ & $11.8891 * * *$ \\
$R^{2}$ & $88.32 \%$ & $89.11 \%$ & $74.22 \%$ & $86.61 \%$ & $83.28 \%$ \\
\hline
\end{tabular}

B.

\begin{tabular}{llllll} 
& $(6,6)$ & $(7,5)$ & $(\mathrm{Q} 1, \mathrm{Q} 2)$ & $(\mathrm{Q} 2, \mathrm{Q} 3)$ & $(\mathrm{Q} 3, \mathrm{Q} 4)$ \\
\hline$R_{i, t}^{\text {Fam }} \cdot D_{I}^{S}$ & $0.0047^{* *}$ & $0.0048^{* *}$ & $0.0056^{* *}$ & 0.0028 & $0.0056^{* *}$ \\
$R_{i, t}^{\text {Fam }} \cdot D_{s}^{S}$ & 0.0034 & 0.0025 & 0.0028 & -0.0001 & 0.0031 \\
$R_{i, t}^{\text {Seg }} \cdot D_{I}^{S}$ & -0.0007 & 0.0026 & $-0.0053^{* *}$ & 0.0002 & $-0.0073^{* *}$ \\
$R_{i, t}^{\text {Seg }} \cdot D_{s}^{S}$ & -0.0027 & 0.0017 & -0.0038 & -0.0014 & $-0.0084 * * *$ \\
$\sigma_{i, t}-1$ & $-3.5000^{* * *}$ & $-2.9157^{* * *}$ & $-4.8138^{* * *}$ & $-3.8892 * * *$ & $-3.6295^{* * *}$ \\
$\Delta \sigma_{\text {med }}$ & $13.6676^{* * *}$ & $12.8787^{* * *}$ & $6.9834 * * *$ & $14.3356^{* * *}$ & $11.8775^{* * *}$ \\
$R^{2}$ & $88.32 \%$ & $83.71 \%$ & $74.06 \%$ & $86.55 \%$ & $83.24 \%$
\end{tabular}

Note: This table presents the regression results from the family tournament model (1). $R_{i, t}^{F a m}$ and $R_{i, t}^{\text {Seg }}$ are the family and segment ranks respectively based on funds' alphas estimated by the Carhart 4 factors model. $D_{1}\left(D_{s}\right)$ is the dummy variable which equals to $1(0)$ when fund $i$ belongs to a large (small) fund family. $\sigma_{i, t}-1$ is the risk level that fund $i$ is exposed to in the ranking period and $\Delta \sigma_{m e d}$ is the median difference of the segment volatility. Funds' daily returns from 3 UK IMA segments, UK All Companies, UK Equity Income and UK Small Companies, are examined for the sample years between 2001 and 2010. Panel A reports the results when the fund families are sorted by funds' aggregate market size, while in Panel B results are sorted by the number of funds in the family. Column 1 presents the results for the 6-month ranking period and column 2 shows the results when the ranking period is 7 months and the post-ranking period is 5 months. Columns $4-6$ report the results when a quarterly tournament is considered. All the results are based on a time fixed panel regression. ${ }^{* *},{ }^{* *}$ and $*$ indicate significance at the $1 \%, 5 \%$ and $10 \%$ level.

alpha from the Carhart 4 factor model as the ranking criterion. Similar tournament behaviour is found in the large sized families, where $R_{i, t}^{\text {Fam }} * D_{i}^{V}$ is found to have a significant and positive loading. Its parameter value as shown in table 3 is very close to that of the coefficients on $R_{i, t}^{F a m} * D_{i}^{V}$ in Panel A of table 2, with only an 8 -basis-point difference. Funds within small sized families are not found to increase their risk exposure significantly. Therefore, our analysis 
indicates a pervasive phenomenon of family tournament among large sized fund families. However, evidence reported in table 3 does not support the segment tournament in both large and small families, as none of the coefficients on $R_{i, t}^{S e g}$ are significantly different from 0 .

Employment concern is another incentive that can trigger managers' risk altering. (Kempf et al. 2009) find that mangers change their risk level differently during distinct market condition. They argue that mid-year winners increase their risk exposure more than the mid-year losers in bear market since the losing managers are more concerned about their jobs (employment incentive dominant). Opposite situation occurs in bull market when compensation is the major concern among the managers (compensation incentive dominant). To further test the distinguishing risk shifting during these two types of market condition, we apply the empirical model suggested by Kempf et al. (2009). The model is described as following:

$$
\Delta \sigma_{i, t}=\alpha_{i}+\beta_{i}^{(1)} R_{i, t}^{\text {Fam }} D^{\text {Com }}+\beta_{i}^{(2)} R_{i, t}^{\text {Fam }} D^{E m p}+\varepsilon_{i, t}
$$

where $R_{i, t}^{\text {Fam }}$, the fund's family rank, is interacted with the dummy variable which classify the market condition into bear and bull. ${ }^{5}$ Table 4 reports the results.

The results show significantly distinct risk shifting between the bear and bull market. Mid-year winners are more likely to increase their risk exposure than the mid-year losers when the employment incentive is dominant in that year, whereas the opposite is true when the compensation incentive is dominant in the sampled year. For example, the coefficient is $6.79 \%$ for $R_{i, t}^{\text {Fam }} * D^{C o m}$ and $-4.92 \%$ for $R_{i, t}^{\text {Fam }} * D^{E m p}$ when 6-month ranking period is considered. Also, it seemed that the employment incentive is more sensitive with the risk shifting than the compensation incentive given the coefficient of $R_{i, t}^{F a m} * D^{E m p}$ is larger in absolute value. Column 3 of table 4 reports similar results as those shown in the previous column.

The findings in table 4 further confirm our concerns regarding to the risk taking driven by employment incentive. Increasing risk exposure also adds more uncertainties to the holding portfolio, which may lead to

5. We adopt the method suggested by Kempf et al. (2009) to classify the sampled years into bear and bull ones. Thus, 2003, 2005, 2006, 2009 and 2010 is considered as bull years (compensation incentive dominant) while the rest of the sampled years are in bear condition (employment incentive dominant). 
TABLE 4. Employment and compensation driven risk taking

\begin{tabular}{lcc}
\hline Risk taking & $(6,6)$ & $(7,5)$ \\
\hline$R_{i, t}^{\text {Fam }} \cdot D^{\text {Emp }}$ & $0.0679 * * *$ & $0.0668^{* * *}$ \\
$R_{i, t}^{\text {Fam }} \cdot D^{\text {Cam }}$ & $(4.24)$ & $(4.45)$ \\
$R^{2}$ & $-0.0492 * * *$ & $-0.0577^{* * *}$ \\
\hline
\end{tabular}

Note: This table presents the regression results from the family tournament model (3). $R_{i, t}^{\text {Fam }}$ is the family ranks based on funds' observed mean returns. $D^{\text {Com }}\left(D^{E m p}\right)$ is the dummy variable which equals to 1 when the sampled year is compensation (employment) incentive dominant. We classify the market into bull (bear) when the mid-year return of the FTSE All Share Index is positive (negative). Funds' daily returns from 3 UK IMA segments, UK All Companies, UK Equity Income and UK Small Companies, are examined for the sample years between 2001 and 2010. Column 2 presents the results for the 6-month ranking period and column 3 shows the results when the ranking period is 7 months and the post-ranking period is 5 months. All the results are based on a time fixed panel regression. ***,** and * indicate significance at the $1 \%, 5 \%$ and $10 \%$ level.

even worse performance in the future. Since underperforming mangers are under more employment pressures, they are more cautions with risk taking than the over performing ones. Meanwhile, the higher sensitivity between the risk shifting and employment concerns is also consistent with our overall finding on the relation between risk taking and fund previous performance in table 2, where interim winners tend to increase their level of risk more than the loser for all sampled years.

The research extend the analysis to look at the tournament behaviour on the family basis. Fund families are ranked according to their mean value weighted returns in the ranking period and we create dummy variables indicating a star ( $\mathrm{dog})$ family when it has at least one top performing (bottom performing) fund. The empirical model is formulated as follows:

$$
\begin{aligned}
\Delta \sigma_{i, t}^{\text {Family }}= & \alpha_{i}+\beta_{i}^{(1)} R_{i, t}^{\text {Family }} D_{l}^{V}+\beta_{i}^{(2)} R_{i, t}^{\text {Family }} D_{s}^{V}+\beta_{i}^{(3)} D_{\text {Star }}+ \\
& \beta_{i}^{(4)} D_{\text {Dog }}+\beta_{i}^{(5)} D_{\text {Star }, \text { Dog }}+\beta_{i}^{(6)} \sigma_{i, t-1}+\varepsilon_{i, t}
\end{aligned}
$$

where the risk shifting of the whole family is computed by taking the difference of volatility of families' value weighted returns between the ranking and post-ranking periods. 
TABLE 5. Whole family tournaments

A.

\begin{tabular}{lccccc} 
& $(6,6)$ & $(7,5)$ & $(\mathrm{Q} 1, \mathrm{Q} 2)$ & $(\mathrm{Q} 2, \mathrm{Q} 3)$ & $(\mathrm{Q} 3, \mathrm{Q} 4)$ \\
\hline$R_{i, t}^{\text {Fam }} \cdot D_{I}^{V}$ & 0.0004 & -0.0005 & -0.0005 & 0.0010 & $-0.0015^{*}$ \\
$R_{i, t}^{\text {Fam }} \cdot D_{s}^{V}$ & 0.0006 & -0.0002 & -0.0005 & 0.0009 & -0.0012 \\
$D_{\text {Star }}$ & $0.0013^{* * *}$ & 0.0007 & 0.0011 & $0.0014^{* *}$ & -0.0001 \\
$D_{\text {Dog }}$ & 0.0008 & -0.0003 & -0.0001 & $0.0014^{* *}$ & -0.0003 \\
$D_{\text {Star }, \text { Dog }}$ & $0.0019^{* * *}$ & $0.0014^{* * *}$ & 0.0004 & $0.0015^{* *}$ & -0.0002 \\
$\sigma_{i, t-1}$ & $-15.497 * * *$ & $-15.0568 * * *$ & $-7.8053^{* * *}$ & $-13.5333^{* * *}$ & $-10.3831^{* * *}$ \\
$R^{2}$ & $77.44 \%$ & $65.35 \%$ & $49.01 \%$ & $53.19 \%$ & $26.75 \%$ \\
\hline
\end{tabular}

B.

\begin{tabular}{lccccc} 
& $(6,6)$ & $(7,5)$ & $(\mathrm{Q} 1, \mathrm{Q} 2)$ & $(\mathrm{Q} 2, \mathrm{Q} 3)$ & $(\mathrm{Q} 3, \mathrm{Q} 4)$ \\
\hline$R_{i, t}^{\text {Fam }} \cdot D_{I}^{S}$ & 0.0006 & -0.0003 & -0.0004 & 0.0013 & -0.0011 \\
$R_{i, t}^{\text {Fam }} \cdot D_{s}^{S}$ & 0.0004 & -0.0003 & -0.0006 & 0.0007 & $-0.0016^{*}$ \\
$D_{\text {Star }}$ & $0.0013^{* * *}$ & 0.0007 & 0.0011 & $0.0013^{*}$ & -0.0001 \\
$D_{\text {Dog }}$ & 0.0007 & -0.0003 & -0.0001 & $0.0013^{* *}$ & -0.0004 \\
$D_{\text {Star,Dog }}$ & $0.0018^{* * *}$ & $0.0013^{* *}$ & 0.0003 & $0.0013^{* *}$ & -0.0003 \\
$\sigma_{i, t-1}$ & $-15.468^{* * *}$ & $-15.0265^{* * *}$ & $-7.7978^{* * *}$ & $-13.4907 * * *$ & $-10.3292^{* * *}$ \\
$R^{2}$ & $77.48 \%$ & $65.34 \%$ & $49.00 \%$ & $53.30 \%$ & $26.96 \%$ \\
\hline
\end{tabular}

Note: This table presents the regression results on risk shifting in the family tournament. $R_{i, t}^{\text {Fam }}$ is the rank of the family return, which is calculated by using the value weighted return of funds within the same family. $D_{1}\left(D_{s}\right)$ is the dummy variable, which equals to $1(0)$ when family is a large (small) fund family. $D_{\text {Star }}\left(D_{D o g}\right)$ equals to $1(0)$ when family $i$ is a star (dog) family. $\sigma_{i, t}-1$ is the risk of family $i$ in the ranking period. Funds' daily returns from $3 \mathrm{UK}$ IMA segments, i.e. UK All Companies, UK Equity Income and UK Small Companies, are examined for the sample years between 2001 and 2010. Panel A reports the results when fund families are sorted by the funds' aggregate market size, while in Panel B results are sorted by the number of funds in the family. Column 1 presents the results where 6 months is the cut-off point for a ranking period and column 2 shows the results when the ranking period is 7 months and the post-ranking period is 5 months. Columns 4-6 report the results when a quarterly tournament is considered. All the results are based on a time fixed panel regression. $* * *, * *$ and $*$ indicate significance at the $1 \%, 5 \%$ and $10 \%$ level.

Table 5 reports the regression results from model (4). The coefficients on $R_{i, t}^{\text {Family }} * D_{i}^{V}$ and $R_{i, t}^{\text {Family }} * D_{s}^{V}$ are not significant, indicating that fund families do not participate in the tournament by altering their overall risk level. Both tables 2 and 3 show a distinct difference in risk taking behaviour between winners and losers within the same family, which can offset the risk level taken by their affiliated family. For the small families, those with fewer members are normally 
under the management of the same team, and with similar investment strategies would be less active in participating in tournament. Furthermore, both $D_{\text {Star }}$ and $D_{\text {Star,Dog }}$ have significant coefficients in the $(6,6)$ interval of Panel A, with 13 and 19 basis points, suggesting that funds within the star families tend to take more risks. This is consistent with the previous findings, in which top performing funds increase their risks more than bottom performing ones. Particularly, since star families contain funds ranked in the top $10 \%$ of the corresponding segment, the results given in table 5 imply that the increase of the families' overall risk is mainly attributable to the risk shifting undertaken by the star funds, while the other peer funds, especially the dog funds, maintain stable risk levels. This finding can also be explained as the direct consequence of family subsidization, since fund companies keep star funds informed with more valuable information in order to utilize the spillover effect.

\section{B. Risk characteristics in segment and family tournaments}

The paper now extend the investigation to deploy alternative risk measures in analysing the tournament behaviour. Tables 6 and 7 report results when the market beta and the idiosyncratic risk are used to compute the level of risk shifting.

In tables 6 and 7, the statistical significance of coefficients on $R_{i, t}^{\text {Fam }} * D_{i}^{V}$ in both the $(6,6)$ and $(7,5)$ intervals of Panel A suggests that leading managers of the family increase more of their systematic risk in the tournament than do the losing ones. This result is further enhanced in Panel B when families are sorted according to the number of their underlying funds, i.e. with a parameter value of $6.23 \%$ and $7.88 \%$ respectively for the $(6,6)$ and $(7,5)$ intervals. The possible reason lies behind might be due to mangers' increasing holding of the high beta stocks. The performance attribution analysis conducted in Section V, part D, also support that the increasing of market beta contribute to winners' outperformance against the losers in the family tournament. While cross subsidization can bring more resources to finance major strategy changes by the winning funds, it seems reasonable for the winning funds to decrease uncertainty resulting from holding small value equities, since previous evidence suggests that in general the index-linked funds outperform the actively managed funds. The results in Panels A and B of table 7 also confirm this finding by showing no statistically significant evidence of family tournament when 
TABLE 6. Family and segment tournaments (Market Beta)

A.

\begin{tabular}{llllll} 
& $(6,6)$ & $(7,5)$ & $(\mathrm{Q} 1, \mathrm{Q} 2)$ & $(\mathrm{Q} 2, \mathrm{Q} 3)$ & $(\mathrm{Q} 3, \mathrm{Q} 4)$ \\
\hline$R_{i, t}^{\text {Fam }} \cdot D_{I}^{V}$ & $0.0363 *$ & $0.0497^{* * *}$ & $0.0484 * *$ & 0.0180 & $0.0408^{* * *}$ \\
$R_{i, t}^{\text {Fam }} \cdot D_{s}^{V}$ & 0.0209 & $0.0448^{* *}$ & 0.0156 & -0.0049 & $0.0572^{* * *}$ \\
$R_{i, t}^{\text {Seg }} \cdot D_{I}^{V}$ & -0.0137 & -0.0035 & $-0.0524 * * *$ & $0.0470^{* *}$ & -0.0193 \\
$R_{i, t}^{\text {Seg }} \cdot D_{s}^{V}$ & $-0.0471^{* *}$ & -0.0303 & $-0.0455^{* *}$ & 0.0113 & $-0.0578^{* * *}$ \\
$\beta_{i, t}-1$ & $-2.3525^{* * *}$ & $-3.4309 * * *$ & $-0.2903 * * *$ & $-0.1070^{* * *}$ & $-0.3457 * *$ \\
$\Delta \beta_{\text {med }}$ & $12.3390^{* * *}$ & $11.8658^{* * *}$ & $0.5272^{* * *}$ & $0.8219 * * *$ & $0.4662 * * *$ \\
$R^{2}$ & $44.12 \%$ & $38.27 \%$ & $65.64 \%$ & $41.17 \%$ & $59.19 \%$
\end{tabular}

B.

\begin{tabular}{llllll} 
& $(6,6)$ & $(7,5)$ & $(\mathrm{Q} 1, \mathrm{Q} 2)$ & $(\mathrm{Q} 2, \mathrm{Q} 3)$ & $(\mathrm{Q} 3, \mathrm{Q} 4)$ \\
\hline$R_{i, t}^{\text {Fam }} \cdot D_{I}^{S}$ & $0.0623^{* * *}$ & $0.0788^{* * *}$ & $0.0781^{* * *}$ & $0.0338^{* *}$ & $0.0782^{* * *}$ \\
$R_{i, t}^{\text {Fam }} \cdot D_{s}^{S}$ & -0.00236 & 0.0202 & -0.0051 & -0.0183 & $0.0243^{*}$ \\
$R_{i, t}^{\text {Seg }} \cdot D_{I}^{S}$ & $-0.0569^{* *}$ & $-0.0396^{*}$ & $-0.0909^{* * *}$ & 0.0127 & $-0.0704 * * *$ \\
$R_{i, t}^{\text {Seg }} \cdot D_{s}^{S}$ & -0.0136 & 0.0051 & -0.0159 & $0.0381^{* *}$ & -0.0053 \\
$\beta_{i, t}-1$ & $-2.3124 * * *$ & $-3.4064 * * *$ & $-0.2902^{* * *}$ & $-0.1031 * * *$ & $-0.3456^{* * *}$ \\
$\Delta \beta_{\text {med }}$ & $12.3586^{* * *}$ & $11.8913^{* * *}$ & $0.5345^{* * *}$ & $0.8244 * * *$ & $0.4699 * * *$ \\
$R^{2}$ & $44.25 \%$ & $38.31 \%$ & $65.88 \%$ & $41.01 \%$ & $59.08 \%$ \\
\hline
\end{tabular}

Note: This table presents the regression results from model (1) where $\Delta \sigma_{i, t}$ is given by the difference of the market beta between the ranking and post-ranking periods. The market beta is estimated by the Carhart 4 factors model. $R_{i, t}^{\text {Fam }}$ and $R_{i, t}^{\text {Seg }}$ are the family and segment ranks based on funds' daily returns. $D_{l}\left(D_{s}\right)$ is the dummy variable which equals to $1(0)$ when fund $i$ belongs to a large (small) fund family. $\beta_{i, t}-1$ is the market beta of fund $i$ in the ranking period and $\Delta \beta_{\text {med }}$ is the median difference of the segment beta. Funds' daily returns in the sample period of 2001 to 2010 from 3 UK IMA segments, i.e. UK All Companies, UK Equity Income and UK Small Companies, are used to estimate the market beta. Panel A reports the results when fund families are sorted by funds' aggregate market size, while in Panel B results are sorted by the number of funds in the family. Column 1 presents the results where 6 months is taken as the cut-off point for the ranking period and column 2 shows the results when the ranking period is 7 months and the post-ranking period is 5 months. Columns 4-6 report the results when a quarterly tournament is considered. All the results are based on a time fixed panel regression. $* * *, * *$ and $*$ indicate significance at the $1 \%, 5 \%$ and $10 \%$ level.

the idiosyncratic risk is considered.

Compared with family tournaments, in table 6 no evidence is found to support the shifts in risk taking behaviour in terms of systematic risk in the segment tournament. However, the losing funds are found to increase their idiosyncratic risk exposure more than the winning funds in the second half of the calendar year, as shown in table 6 where $R_{i, t}^{S e g} * D_{i}$ has a coefficient of $-6.1 \%$ in Panel A and $-8.4 \%$ in Panel B. 
TABLE 7. Family and segment tournaments (Idiosyncratic Risk)

A.

\begin{tabular}{|c|c|c|c|c|c|}
\hline & $(6,6)$ & $(7,5)$ & (Q1,Q2) & (Q2,Q3) & $(\mathrm{Q} 3, \mathrm{Q} 4)$ \\
\hline$R_{i, t}^{\text {Fam }} \cdot D_{I}^{V}$ & 0.0035 & 0.0026 & -0.0004 & 0.0036 & 0.0035 \\
\hline$R_{i, t}^{\text {Fam }} \cdot D_{s}^{V}$ & 0.0024 & 0.0012 & 0.0004 & 0.0007 & $0.0050 * *$ \\
\hline$R_{i, t}^{S e g} \cdot D_{I}^{V}$ & $-0.0061 * * *$ & -0.0036 & 0.0031 & $-0.0054 * *$ & $-0.0075^{* *}$ \\
\hline$R_{i, t}^{S e g} \cdot D_{s}^{V}$ & $-0.0089 * * *$ & $-0.0051 * *$ & 0.0004 & $-0.0050 * *$ & $-0.0075 * * *$ \\
\hline$\sigma_{\varepsilon i, t}-1$ & $-3.5591 * * *$ & -3.1808 & $-4.5610 * * *$ & $-3.9013 * * *$ & $-3.6651 * * *$ \\
\hline$\Delta \sigma_{\text {вmed }}$ & $12.5259 * * *$ & 11.5825 & $5.1820 * * *$ & $13.7519 * * *$ & $10.4571 * * *$ \\
\hline$R^{2}$ & $78.89 \%$ & $79.10 \%$ & $40.31 \%$ & $72.76 \%$ & $73.44 \%$ \\
\hline
\end{tabular}

B.

\begin{tabular}{llllll} 
& $(6,6)$ & $(7,5)$ & $(\mathrm{Q} 1, \mathrm{Q} 2)$ & $(\mathrm{Q} 2, \mathrm{Q} 3)$ & $(\mathrm{Q} 3, \mathrm{Q} 4)$ \\
\hline$R_{i, t}^{\text {Fam }} \cdot D_{I}^{S}$ & 0.0036 & 0.0003 & 0.0008 & 0.0019 & 0.0035 \\
$R_{i, t}^{\text {Fam }} \cdot D_{s}^{S}$ & 0.0022 & 0.0031 & -0.006 & 0.0022 & $0.0049^{* *}$ \\
$R_{i, t}^{\text {Seg }} \cdot D_{I}^{S}$ & $-0.0084^{* * *}$ & -0.0028 & 0.0015 & $-0.0051^{* *}$ & $-0.0049^{*}$ \\
$R_{i, t}^{\text {Seg }} \cdot D_{s}^{S}$ & $-0.0072^{* * *}$ & $-0.0067^{* *}$ & 0.0012 & $-0.0053^{* *}$ & $-0.0095^{* * *}$ \\
$\sigma_{\varepsilon i, t}-1$ & $-3.5715^{* * *}$ & $-3.1907^{* * *}$ & $-4.5775^{* * *}$ & $-3.9056^{* * *}$ & $-3.6625^{* * *}$ \\
$\Delta \sigma_{\varepsilon m e d}$ & $12.5394 * * *$ & $11.6465^{* * *}$ & $5.1838^{* * *}$ & $13.7525^{* * *}$ & $10.4791^{* * *}$ \\
$R^{2}$ & $78.86 \%$ & $79.12 \%$ & $40.24 \%$ & $72.74 \%$ & $73.48 \%$ \\
\hline
\end{tabular}

Note: This table presents the regression results from model (1) where $\Delta \sigma_{i, t}$ is given by the difference of the market beta between the ranking and post-ranking periods. The idiosyncratic risk is proxied by the standard deviation of the error term from the Carhart 4 factors model. $R_{i, t}^{\text {Fam }}$ and $R_{i, t}^{\text {Seg }}$ are the family and segment ranks based on funds' daily returns. $D_{\text {large }}\left(D_{\text {small }}\right)$ is the dummy variable which equals to $1(0)$ when fund $i$ belongs to a large (small) fund family. $\sigma_{\varepsilon i, t}^{2}-1$ is the market beta of fund $i$ in the ranking period and $\Delta \sigma_{\text {zmed }}^{2}$ is the median difference of the segment beta. Funds' daily returns in the sample period of 2001 to 2010 from 3 UK IMA segments, i.e. UK All Companies, UK Equity Income and UK Small Companies, are used to estimate the market beta. Panel A reports the results when fund families are sorted by funds' aggregate market size, while in Panel B results are sorted by the number of funds in the family. Column 1 presents the results when the cut-off point for the ranking period is 6 months, and column 2 shows the results when the ranking period is 7 months and the post-ranking period is 5 months. Columns $4-6$ report the results when a quarterly tournament is present. All the results are based on a time fixed panel regression. $* * *, * *$ and $*$ indicate significance at the $1 \%, 5 \%$ and $10 \%$ level.

This result remains significant in the small family case. HSZ find similar results in their research. They hold that underperforming funds tend to take more idiosyncratic risks by increasing portfolio concentration or changing stock selection. But such an effort brings no positive feedback to performance consequences. Similar arguments can be found in Ang et al. (2006), for example. Given disproportionate 
responses of the growing cash inflows, it comes as no surprise to see that losing funds choose to increase their exposure to uncertainty surrounding their portfolio with a view to improving performance in the segment tournament.

\section{Performance comparison in family tournaments}

Despite the evidence of top funds' performance persistence after risk shifting, it remains to be seen whether such funds can outperform their peers in the same family. To answer this question, in this section we compare the performance between the mid-year winners and losers under different levels of risk shifting. The results are reported in tables 8.

In the first column of table 8, we sort funds into 5 groups RS group according to their levels of risk shifting. The funds are then classified into the winner and loser groups according to their mid-year performance. Performance of the funds is measured by the mean returns, the CAPM alphas, the 3-factor alphas and the 4-factor alphas. In Panel A where the funds' segment ranks are used to sort winner/loser groups, the results suggest that the losing funds cannot outperform the winning ones for all evaluation measures when their risk taking is at a low level. The mean returns from the winning group exceed those of the losing group by $3.74 \%$, statistically significant at the $1 \%$ level. Similar results can be drawn when the Jensen alpha measure is used. However, the winning funds cannot beat the losing ones when they take more risk, since the performance differences between the two groups are not statistically significant for the $5^{\text {th }} \mathrm{RS}$ group. Recalling the results in table 2, where the mid-year losers tend to increase their risk exposure more than the winners in segment tournaments, the performance consequences of funds' risk shifting, however, suggest that it does not make sense for the losing funds to take extra risks. Therefore, winner's risk increasing cannot but be an indication of inferior ability or a sign of the agency problem (See similar argument in HSZ).

In Panel B of table 8, family ranks are used to sort funds into winning and losing groups. Similar results are documented, that mid-year winners outperform the losers in the $1^{\text {st }} \mathrm{RS}$ group. However, at a higher level of risk shifting, table 8 shows a mixed result between performance measures based on raw returns and Jensen alphas. Specifically, mid-year losers can beat the winners in terms of observed returns, but underperform them in Jensen alpha. The difference is 
$-5.34 \%$ in returns and $3.59 \%$ in CAPM alpha; both are significant at the $1 \%$ level. Such differences become smaller when the 3-factor and 4-factor alphas are considered, but remain statistically significant. Certainly, winners' underperformance could be due to mean reversion in their main holdings' returns. In table 6 , the results have already shown that increasing portfolios' market beta can be a channel of risk shifting. Fund managers may deliberately select large-cap equities with good past performance, or keep the position of their original holdings to maintain their leading positions. But those equities might not perform persistently, which can lower the overall returns of the winners.

On the other hand, the higher value of Jensen alphas delivered by the mid-year winners implies that those managers possess superior stock selection abilities so that they are able to re-construct their portfolios by picking up more underpriced stocks. Meanwhile, judging by the increasing magnitude of alphas obtained from the 3-factor model and the 4-factor model, it is plausible that managers' superior ability is not attributable to increased holdings of the size and book to market portfolio, or the momentum portfolio.

In addition, Panel B shows that the mid-year losers tend to keep their risk at a stable level to mimic the performance of the winners, which may explain why the performance differences between the winner and loser groups are the smallest. HSZ find the similar result that funds with more stable risk levels exhibit the best performance. In a strategic tournament, mid-year winners show risk taking behaviour similar to that of the mid-year losers, since the winning funds now have more access to new capital to manipulate their portfolios. The performance improvement in terms of the Jensen alphas following changes in the risk taking indicates the superior stock selection ability of the winning managers. But when the magnitude of the risk shifting decreases, the winners lose their competitive edge; hence both winners and losers reduce to adopt a similar investment strategy, and so no performance consequence is shown here. However, in the $1^{\text {st }} \mathrm{RS}$ group, where the risk shifting is limited in magnitude or even changes to take on less rather than more risk exposure, mid-year losers still cannot outperform the winners, for the reason that the winners can liquidate some of their holdings to lock on the cash profits (See for example HSZ). ${ }^{6}$

6. We also extend our performance consequences analysis to consider a 7-5 interval segment/family tournament, and similar results are therefore documented. Hence we omit the detailed results but can provide them on request. 


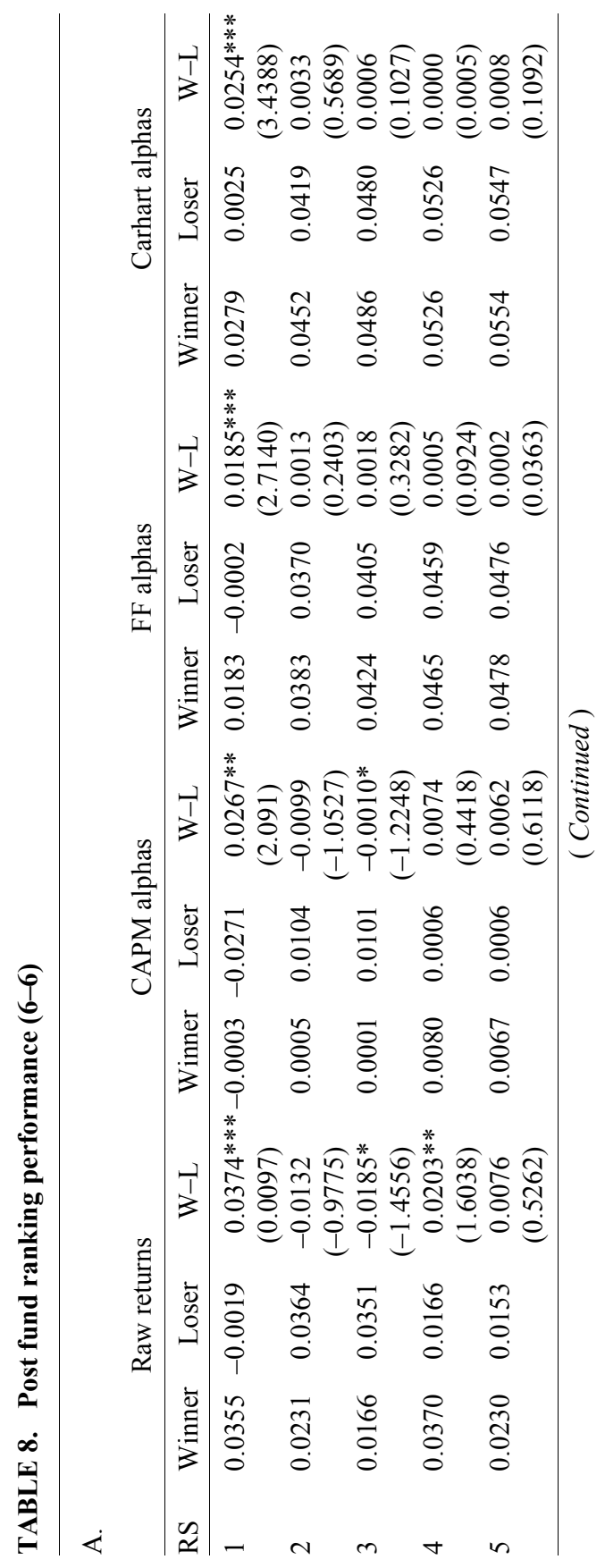




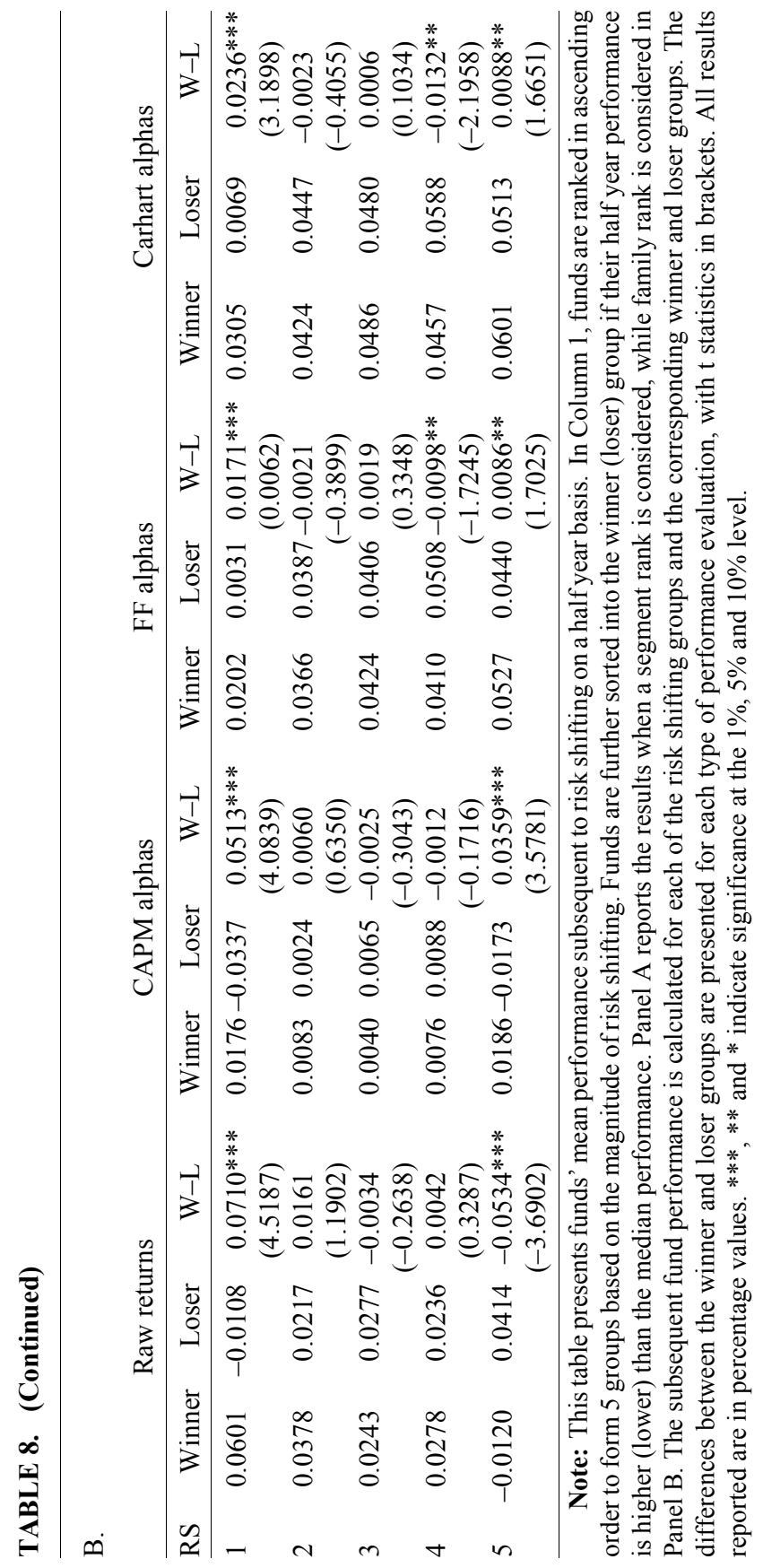




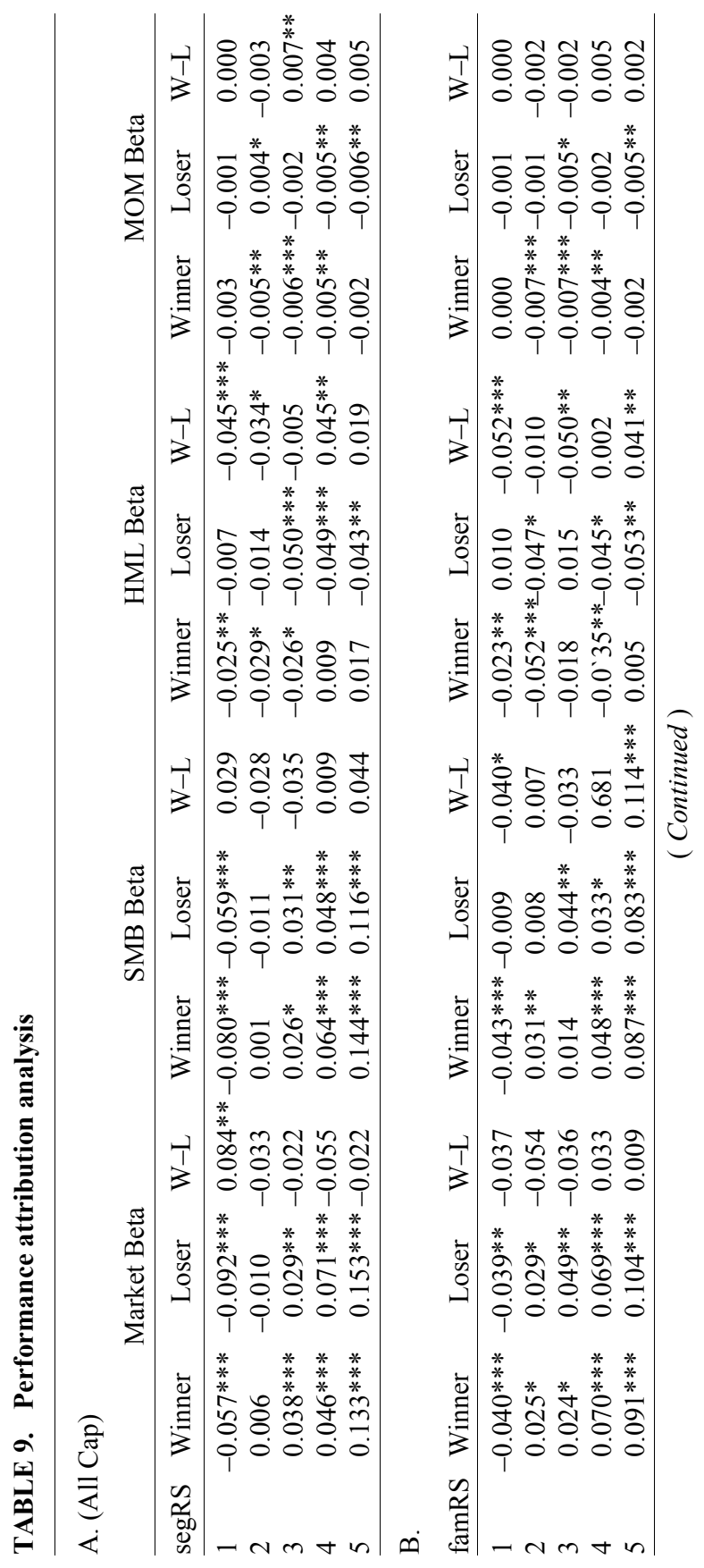




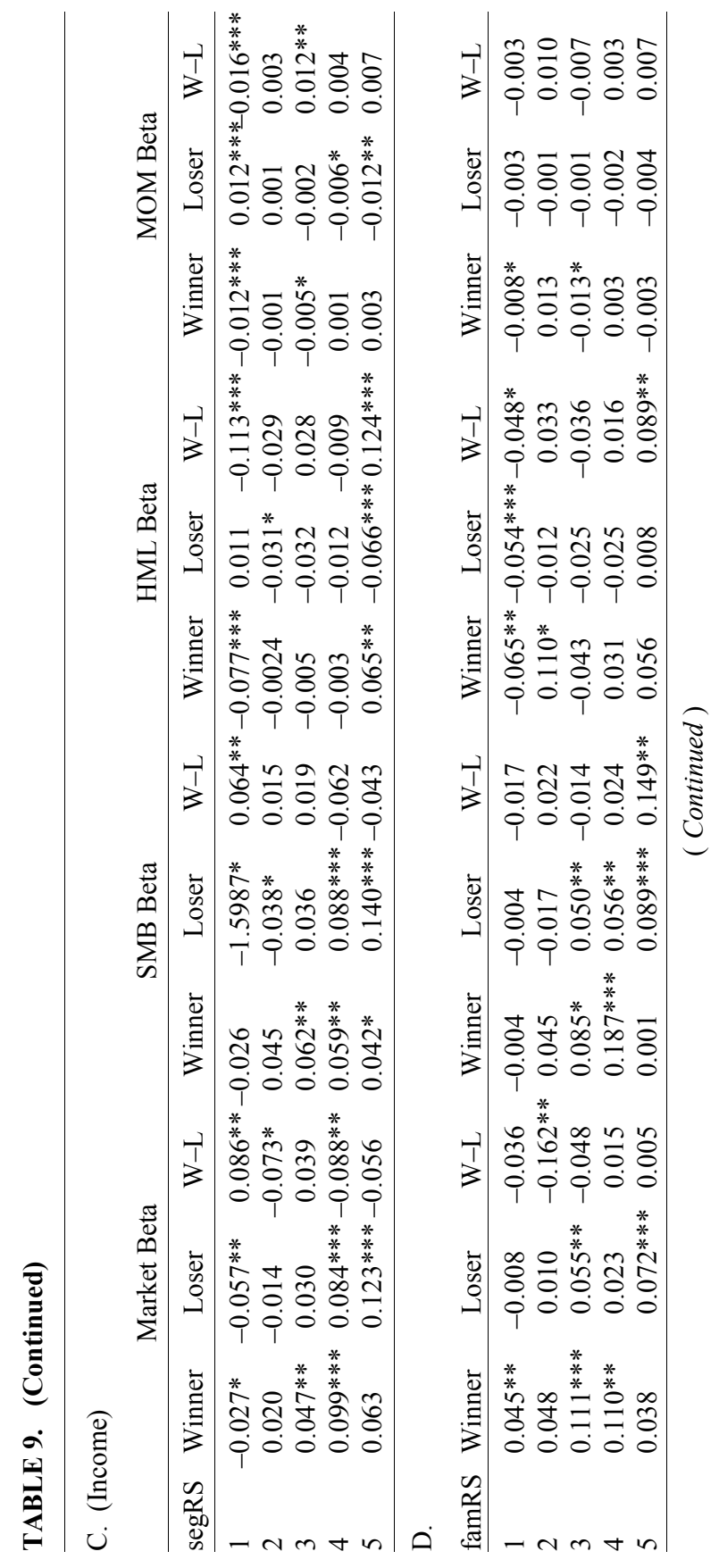




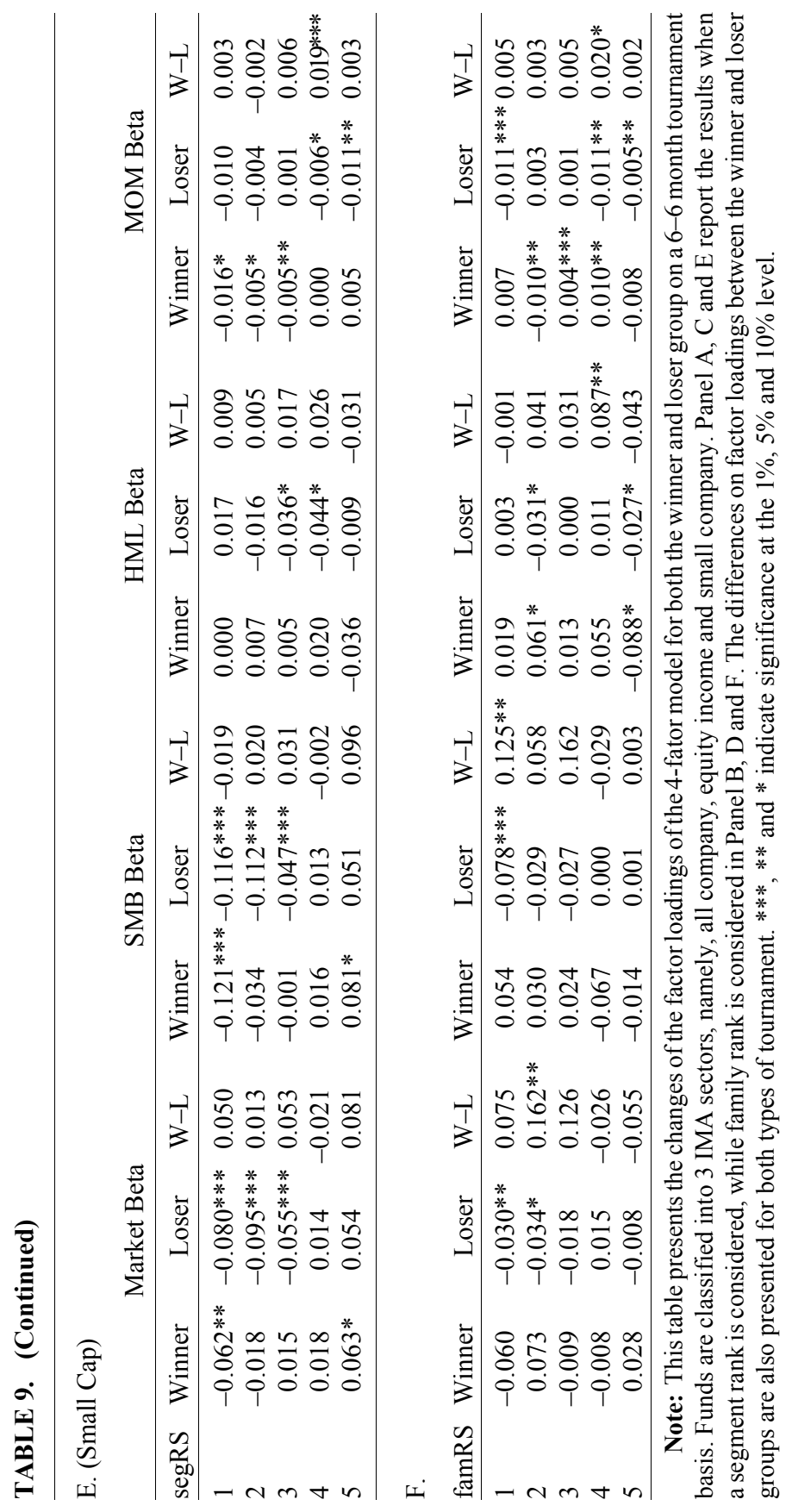


To provide further insights into winning managers' trading strategies in the tournament table 9 undertake a performance attribution analysis which compare the loadings of each pricing factors (betas) on the half-year basis. In Panel A where funds from the sector of All UK Companies are considered, the results suggest that betas of the market and size portfolio from both the winning and losing funds increase significantly with their risk exposure in the second half of the year while opposite results are found on the betas of book to market and momentum portfolio. Similar results on the market and size portfolio are found when conducting the analysis on the funds from the UK income sector, but no significant trading pattern on the market and size portfolio is documented in the high RS group. In terms of the comparison between the winning and losing funds, for funds within the all company and income sectors, we find evidence that by increasing their half-year risk winners have significant higher beta on the size and book to market portfolio than the losers when engaging in family tournament. Particularly, the winners have a beta exceeding those of the losers by 0.144 on average on the size portfolio in the top RS group, and the gap remains at 0.041 on the book to market portfolio and it is statistically significant. No evidence is found to support that the momentum portfolio contribute positively when winners increase their half-year risk in the family tournament. Such a results is consistent with the findings by Cuthbertson et al. (2008) where momentum factors are generally not significant at the individual fund level.

The research extends its investigation to examine the size effect in the performance consequences to the risk shifting. Our results suggest a consistent outperforming on the alphas delivered by the funds who largely increase their risk exposure in the family tournament. In table 10 , funds are further classified into 5 groups according to their size. In Panel A where segment tournament is considered the findings agree with the previous results in which winners in the low RS group outperform the losers, particular for the group of small funds. But no significant pattern is documented on comparing winning/losing funds when turning to higher RS group. Panel B reports the analysis based on the family tournament, the results suggest that large funds in the winner group are more likely to outperform the losing ones with the similar size scale by increasing their second half-year risk exposure. However, significant performance difference is documented between the winning and losing funds in the small size group when fund managers retain or decrease their second half-year risk level. Such results persistent 
TABLE 10. Post fund ranking size adjusted performance

\begin{tabular}{|c|c|c|c|c|c|}
\hline \multicolumn{6}{|l|}{ A. } \\
\hline & & Raw returns & CAPM alphas & FF alphas & Carhart alphas \\
\hline $\mathrm{RS}$ & Size & W-L & W-L & W-L & W-L \\
\hline \multirow[t]{5}{*}{1} & 1 & $\begin{array}{l}-0.0132 \\
(-0.43)\end{array}$ & $\begin{array}{l}0.0573 * * * \\
(2.39)\end{array}$ & $\begin{array}{l}0.0637 * * * \\
(4.78)\end{array}$ & $\begin{array}{l}0.0692 * * * \\
(4.99)\end{array}$ \\
\hline & 2 & $\begin{array}{l}0.0096 \\
(0.29)\end{array}$ & $\begin{array}{l}0.0106 \\
(0.43)\end{array}$ & $\begin{array}{l}0.0556^{* * *} \\
(2.70)\end{array}$ & $\begin{array}{l}0.0450 * * * \\
(3.27)\end{array}$ \\
\hline & 3 & $\begin{array}{l}0.0088 \\
(0.31)\end{array}$ & $\begin{array}{l}0.0325^{*} \\
(1.50)\end{array}$ & $\begin{array}{l}0.0157 \\
(0.06)\end{array}$ & $\begin{array}{l}0.0227^{*} \\
(1.55)\end{array}$ \\
\hline & 4 & $\begin{array}{l}-0.0050 \\
(-0.15)\end{array}$ & $\begin{array}{l}0.0343 * \\
(1.41)\end{array}$ & $\begin{array}{l}0.0150 * \\
(1.36)\end{array}$ & $\begin{array}{l}0.0100 \\
(0.97)\end{array}$ \\
\hline & 5 & $\begin{array}{l}0.0662 * * * \\
(2.23)\end{array}$ & $\begin{array}{l}-0.0072 \\
(-0.37)\end{array}$ & $\begin{array}{l}0.0213^{*} \\
(1.63)\end{array}$ & $\begin{array}{l}0.0150 \\
(1.01)\end{array}$ \\
\hline \multirow[t]{5}{*}{2} & 1 & $\begin{array}{l}-0.0067 \\
(-0.21)\end{array}$ & $\begin{array}{l}0.0057 \\
(0.26)\end{array}$ & $\begin{array}{l}0.0260 * * \\
(2.05)\end{array}$ & $\begin{array}{l}0.0127 \\
(0.92)\end{array}$ \\
\hline & 2 & $\begin{array}{l}0.0016 \\
(0.05)\end{array}$ & $\begin{array}{l}-0.0028 \\
(-0.13)\end{array}$ & $\begin{array}{l}0.0291^{*} \\
(0.54)\end{array}$ & $\begin{array}{l}0.0293 * * * \\
(2.37)\end{array}$ \\
\hline & 3 & $\begin{array}{l}0.0458^{*} \\
(1.45)\end{array}$ & $\begin{array}{l}0.0407 * * \\
(1.84)\end{array}$ & $\begin{array}{l}0.0251 * * \\
(2.00)\end{array}$ & $\begin{array}{l}0.0250^{* *} \\
(1.90)\end{array}$ \\
\hline & 4 & $\begin{array}{l}-0.0076 \\
(-0.26)\end{array}$ & $\begin{array}{l}0.0249^{*} \\
(1.39)\end{array}$ & $\begin{array}{l}0.0188^{*} \\
(1.55)\end{array}$ & $\begin{array}{c}0.0091 \\
(0.70)\end{array}$ \\
\hline & 5 & $\begin{array}{l}-0.0045 \\
(-0.15)\end{array}$ & $\begin{array}{l}0.0432 * * * \\
(2.23)\end{array}$ & $\begin{array}{l}0.0300^{* * *} \\
(2.61)\end{array}$ & $\begin{array}{l}0.0270^{* *} \\
(2.26)\end{array}$ \\
\hline \multirow[t]{5}{*}{3} & 1 & $\begin{array}{l}0.0004 \\
(0.01)\end{array}$ & $\begin{array}{l}-0.0136 \\
(-0.65)\end{array}$ & $\begin{array}{l}0.0174^{*} \\
(1.44)\end{array}$ & $\begin{array}{l}0.0046 \\
(0.36)\end{array}$ \\
\hline & 2 & $\begin{array}{l}0.0126 \\
(0.38)\end{array}$ & $\begin{array}{l}0.0568 * * * \\
(2.36)\end{array}$ & $\begin{array}{l}0.0447 * * * \\
(3.32)\end{array}$ & $\begin{array}{l}0.0525^{* * *} \\
(3.69)\end{array}$ \\
\hline & 3 & $\begin{array}{l}0.0256 \\
(0.76)\end{array}$ & $\begin{array}{l}0.0393 * * \\
(1.85)\end{array}$ & $\begin{array}{l}0.0548^{* * *} \\
(3.91)\end{array}$ & $\begin{array}{l}0.0565^{* * *} \\
(3.91)\end{array}$ \\
\hline & 4 & $\begin{array}{l}-0.0092 \\
(-0.30)\end{array}$ & $\begin{array}{l}0.0300^{*} \\
(1.39)\end{array}$ & $\begin{array}{l}0.0192 * \\
(1.41)\end{array}$ & $\begin{array}{l}0.0248^{* *} \\
(1.76)\end{array}$ \\
\hline & 5 & $\begin{array}{l}-0.0232 \\
(-0.87)\end{array}$ & $\begin{array}{l}0.0123 \\
(0.86)\end{array}$ & $\begin{array}{l}0.0152 * \\
(1.32)\end{array}$ & $\begin{array}{l}0.0075 \\
(0.60)\end{array}$ \\
\hline \multirow[t]{5}{*}{4} & 1 & $\begin{array}{l}0.0499 \\
(1.22)\end{array}$ & $\begin{array}{l}0.0701^{* *} \\
(2.26)\end{array}$ & $\begin{array}{l}0.0729 * * * \\
(3.17)\end{array}$ & $\begin{array}{l}0.0500 \text { ** } \\
(2.01)\end{array}$ \\
\hline & 2 & $\begin{array}{l}0.0344 \\
(1.09)\end{array}$ & $\begin{array}{l}0.0238 \\
(1.15)\end{array}$ & $\begin{array}{l}0.0129 \\
(0.83)\end{array}$ & $\begin{array}{l}-0.0003 \\
(-0.01)\end{array}$ \\
\hline & 3 & $\begin{array}{l}-0.0082 \\
(-0.27)\end{array}$ & $\begin{array}{l}0.0477 \\
(1.11)\end{array}$ & $\begin{array}{l}0.0366^{*} \\
(1.86)\end{array}$ & $\begin{array}{l}0.0013 \\
(0.14)\end{array}$ \\
\hline & 4 & $\begin{array}{l}-0.0279 \\
(-0.98)\end{array}$ & $\begin{array}{l}-0.0052 \\
(-0.29)\end{array}$ & $\begin{array}{l}0.0140 \\
(1.06)\end{array}$ & $\begin{array}{l}0.0157 \\
(1.13)\end{array}$ \\
\hline & 5 & $\begin{array}{l}-0.0029 \\
(-0.10)\end{array}$ & $\begin{array}{l}0.0030 \\
(0.19)\end{array}$ & $\begin{array}{l}0.0213^{* *} \\
(2.07)\end{array}$ & $\begin{array}{l}0.0182^{*} \\
(1.62)\end{array}$ \\
\hline
\end{tabular}

( Continued) 
TABLE 10. (Continued)

\begin{tabular}{|c|c|c|c|c|c|}
\hline \multicolumn{6}{|l|}{ A. } \\
\hline & & Raw returns & CAPM alphas & FF alphas & Carhart alphas \\
\hline$\underline{\mathrm{RS}}$ & Size & $\mathrm{W}-\mathrm{L}$ & $\mathrm{W}-\mathrm{L}$ & $\mathrm{W}-\mathrm{L}$ & $\mathrm{W}-\mathrm{L}$ \\
\hline \multirow[t]{10}{*}{5} & \multirow[t]{2}{*}{1} & $0.0432 *$ & 0.0011 & 0.0141 & 0.0077 \\
\hline & & (1.37) & $(0.67)$ & (1.10) & $(1.00)$ \\
\hline & \multirow[t]{2}{*}{2} & $0.0558 * *$ & 0.0096 & 0.0048 & $0.0121 *$ \\
\hline & & $(1.62)$ & $(0.40)$ & $(0.16)$ & $(0.62)$ \\
\hline & \multirow[t]{2}{*}{3} & 0.0091 & 0.0018 & 0.0029 & -0.0027 \\
\hline & & $(0.26)$ & $(0.08)$ & $(0.25)$ & $(-0.18)$ \\
\hline & \multirow[t]{2}{*}{4} & -0.0347 & 0.0130 & 0.0157 & 0.0053 \\
\hline & & $(-1.13)$ & $(0.69)$ & $(0.35)$ & $(0.70)$ \\
\hline & \multirow[t]{2}{*}{5} & $-0.0484 * *$ & 0.0060 & 0.0102 & 0.0101 \\
\hline & & $(-1.73)$ & $(0.76)$ & $(0.04)$ & $(0.51)$ \\
\hline \multicolumn{6}{|l|}{ B. } \\
\hline & & Raw returns & CAPM alphas & FF alphas & Carhart alphas \\
\hline $\mathrm{RS}$ & Size & $\mathrm{W}-\mathrm{L}$ & $\mathrm{W}-\mathrm{L}$ & $\mathrm{W}-\mathrm{L}$ & $\mathrm{W}-\mathrm{L}$ \\
\hline \multirow[t]{10}{*}{1} & \multirow[t]{2}{*}{1} & -0.0320 & $0.0506^{* * *}$ & $0.0489 * *$ & $0.0304 * * *$ \\
\hline & & $(-1.16)$ & $(2.53)$ & $(2.19)$ & $(2.30)$ \\
\hline & \multirow[t]{2}{*}{2} & -0.0040 & $0.0319^{*}$ & $0.0263 * * *$ & $0.0308^{* * *}$ \\
\hline & & $(-0.16)$ & $(1.63)$ & $(2.50)$ & $(2.65)$ \\
\hline & \multirow[t]{2}{*}{3} & $0.0723 * * *$ & 0.0025 & 0.0126 & $0.0267 * * *$ \\
\hline & & (2.89) & $(0.74)$ & $(0.17)$ & $(2.14)$ \\
\hline & \multirow[t]{2}{*}{4} & 0.0165 & 0.0169 & 0.0184 & 0.0101 \\
\hline & & $(0.66)$ & $(0.12)$ & (1.18) & (1.02) \\
\hline & \multirow[t]{2}{*}{5} & 0.0122 & $0.0191^{*}$ & $0.0149 *$ & 0.0139 \\
\hline & & $(0.48)$ & $(1.27)$ & $(1.41)$ & $(1.18)$ \\
\hline \multirow[t]{10}{*}{2} & \multirow[t]{2}{*}{1} & 0.0282 & $0.0555 * * *$ & $0.0294 * *$ & 0.0181 \\
\hline & & $(0.83)$ & $(2.34)$ & $(1.88)$ & (1.10) \\
\hline & \multirow[t]{2}{*}{2} & -0.0123 & 0.0072 & 0.0049 & 0.0024 \\
\hline & & $(-0.37)$ & $(0.30)$ & $(0.37)$ & $(0.17)$ \\
\hline & \multirow[t]{2}{*}{3} & 0.0083 & 0.0197 & 0.0212 & 0.0060 \\
\hline & & $(0.19)$ & $(0.60)$ & $(1.22)$ & $(0.31)$ \\
\hline & \multirow[t]{2}{*}{4} & $-0.0680 * * *$ & 0.0131 & $-0.0177^{*}$ & $-0.0329 * * *$ \\
\hline & & $(-2.11)$ & $(0.64)$ & $(-1.30)$ & $(-2.30)$ \\
\hline & \multirow[t]{2}{*}{5} & 0.0241 & 0.0127 & 0.0115 & 0.0103 \\
\hline & & $(0.77)$ & $(0.63)$ & $(0.84)$ & $(0.72)$ \\
\hline \multirow[t]{4}{*}{3} & \multirow[t]{2}{*}{1} & 0.0136 & $0.0512 *$ & $0.0351 * *$ & 0.0192 \\
\hline & & $(0.28)$ & $(1.51)$ & (1.77) & $(0.88)$ \\
\hline & \multirow[t]{2}{*}{2} & -0.0201 & 0.0109 & 0.0169 & $0.0303 * *$ \\
\hline & & $(-0.46)$ & $(0.37)$ & (1.05) & $(1.75)$ \\
\hline
\end{tabular}


TABLE 10. (Continued)

\begin{tabular}{|c|c|c|c|c|c|}
\hline & & Raw returns & CAPM alphas & FF alphas & Carhart alphas \\
\hline \multirow[t]{4}{*}{ RS } & Size & W-L & W-L & W-L & W-L \\
\hline & 3 & $\begin{array}{l}0.0506^{*} \\
(1.55)\end{array}$ & $\begin{array}{l}0.0361^{*} \\
(1.56)\end{array}$ & $\begin{array}{l}0.0388^{* * *} \\
(2.82)\end{array}$ & $\begin{array}{l}0.0372^{* * *} \\
(2.56)\end{array}$ \\
\hline & 4 & $\begin{array}{l}0.0658^{* *} \\
(1.91)\end{array}$ & $\begin{array}{l}-0.0051 \\
(-0.25)\end{array}$ & $\begin{array}{l}0.0385^{* * *} \\
(2.60)\end{array}$ & $\begin{array}{l}0.0339 * * \\
(2.19)\end{array}$ \\
\hline & 5 & $\begin{array}{l}0.0034 \\
(0.11)\end{array}$ & $\begin{array}{l}0.0228 \\
(1.22)\end{array}$ & $\begin{array}{l}0.0368^{* * *} \\
(2.95)\end{array}$ & $\begin{array}{l}0.0312^{* * *} \\
(2.33)\end{array}$ \\
\hline \multirow[t]{5}{*}{4} & 1 & $\begin{array}{l}0.0218 \\
(0.60)\end{array}$ & $\begin{array}{l}0.0256 \\
(0.92)\end{array}$ & $\begin{array}{l}0.0278^{*} \\
(1.50)\end{array}$ & $\begin{array}{l}0.0046 \\
(0.24)\end{array}$ \\
\hline & 2 & $\begin{array}{l}0.0345 \\
(0.87)\end{array}$ & $\begin{array}{l}-0.0205 \\
(-0.77)\end{array}$ & $\begin{array}{l}0.0234^{*} \\
(1.30)\end{array}$ & $\begin{array}{l}0.0223 \\
(1.21)\end{array}$ \\
\hline & 3 & $\begin{array}{l}0.0010 \\
(0.03)\end{array}$ & $\begin{array}{l}0.0413^{* *} \\
(1.70)\end{array}$ & $\begin{array}{l}0.0131 \\
(0.77)\end{array}$ & $\begin{array}{l}0.0148 \\
(0.81)\end{array}$ \\
\hline & 4 & $\begin{array}{l}-0.0078 \\
(-0.19)\end{array}$ & $\begin{array}{l}0.0173 \\
(0.59)\end{array}$ & $\begin{array}{l}0.0017 \\
(0.09)\end{array}$ & $\begin{array}{l}0.0007 \\
(0.04)\end{array}$ \\
\hline & 5 & $\begin{array}{l}0.0347^{*} \\
(1.33)\end{array}$ & $\begin{array}{l}0.0059 \\
(0.42)\end{array}$ & $\begin{array}{l}0.0086 \\
(0.75)\end{array}$ & $\begin{array}{c}0.0086 \\
(0.6890)\end{array}$ \\
\hline \multirow[t]{5}{*}{5} & 1 & $\begin{array}{l}0.0306 \\
(1.07)\end{array}$ & $\begin{array}{l}0.0404^{* *} \\
(1.83)\end{array}$ & $\begin{array}{l}0.0189 \\
(0.36)\end{array}$ & $\begin{array}{c}0.0073 \\
(0.0913)\end{array}$ \\
\hline & 2 & $\begin{array}{l}-0.0169 \\
(-0.56)\end{array}$ & $\begin{array}{l}-0.0316^{*} \\
(-1.53)\end{array}$ & $\begin{array}{l}0.0150^{*} \\
(1.30)\end{array}$ & $\begin{array}{r}0.0173^{*} \\
(1.4169)\end{array}$ \\
\hline & 3 & $\begin{array}{l}-0.0151 \\
(-0.54)\end{array}$ & $\begin{array}{l}0.0043 \\
(0.24)\end{array}$ & $\begin{array}{l}0.0220^{* *} \\
(1.89)\end{array}$ & $\begin{array}{c}0.0105 \\
(0.8372)\end{array}$ \\
\hline & 4 & $\begin{array}{l}-0.0585^{* * *} \\
(-2.43)\end{array}$ & $\begin{array}{l}0.0226^{*} \\
(1.62)\end{array}$ & $\begin{array}{l}0.0206^{* * *} \\
(3.02)\end{array}$ & $\begin{array}{l}0.0283^{* * *} \\
(2.6056)\end{array}$ \\
\hline & 5 & $\begin{array}{l}-0.0236 \\
(-0.82)\end{array}$ & $\begin{array}{l}0.0282 * * * \\
(2.46)\end{array}$ & $\begin{array}{l}0.0143^{* * *} \\
(2.26)\end{array}$ & $\begin{array}{l}0.0164 * * * \\
(1.7734)\end{array}$ \\
\hline
\end{tabular}

Note: This table presents the mean performance of fund families subsequent to risk shifting. In Column 1, families are ranked in ascending order to form 5 groups on the basis of the magnitude of risk shifting. Funds are further sorted into groups by their end of year size, in which winners losers are classified according to their half-year performance. Panel A B reports the results based on segment family ranks. The differences between the winner and loser groups are presented for each type of performance evaluation, with $t$ statistics in brackets. All results reported are in percentage values. ${ }^{* * *}, * *$ and $*$ indicate significance at the $1 \%, 5 \%$ and $10 \%$ level.

through various risk-adjusted measures.

Table 11 reports the additional test in which alternative risk measures is considered to build RS groups. Panels A and B indicate that taking more systematic risk might not positively contribute to the average fund performance. For example, the return gap between the 
winner and loser group is $3.88 \%$ in the $1^{\text {st }} \mathrm{RS}$ group but decreases to $-2.47 \%$ when funds increases their market beta. The performance difference in terms of the Carhart alphas also decreases from $2 \%$ to $-0.93 \%$. Similar results can be found in Panel B. Results in reported in table 11 agrees with the our findings in the performance attribution analysis in which the difference on the market beta between the winning and losing groups is not statistically significant. It is therefore argued that the performance improvement found in the family tournament in the previous analysis cannot be attributed to the increased exposure to systematic risk, although a positive relation is documented in previous analysis, suggesting that winning funds tend to increase their market beta in the second half of the year. As mentioned before, an increase in the systematic risk is an indication of the enlargement of the holdings of high beta stocks. Despite the efforts of winning managers to shift portfolio composition to absorb more highly valued equities, mean reversion of the returns of these stocks can demote winners' leading positions.

Results in Panels C and D do not show a clear pattern in the relation between performance consequences and the level of change in the idiosyncratic risks. This finding also confirms the previous results, whereby no significant changes in idiosyncratic risk take place in response to funds' family ranks.

Previous literature suggests that fund families may increase cross-sectional volatility of funds returns to increase the probability of creating star funds. Given the spillover effects of fund flows and the disproportionate response of cash inflows to funds' historical performance, fund families have incentives to encourage risk taking in family tournaments. This requires us to further examine the performance consequences with respect to the efforts by the fund family to promote risk taking.

Table 12 documents a strong relation between the performance improvement and the increase in cross-sectional risks within the fund family. Specifically, dog families are found to significantly increase their cross-sectional total risks to improve performance ranking of their underlying funds. For example, the coefficients on $\Delta \Lambda_{i, t}^{\sigma} D_{\text {Dog }}$ are 4.174, $2.391,4.005$ and 3.225 when fund performance is estimated by the mean returns, CAPM alphas, FF alphas and Carhart alphas, respectively. All of them are significant and the performance consequences respond positively. These results suggest that families with extremely underperforming funds are strongly motivated to promote risk taking of 
TABLE 11. Post-ranking risk characteristics

A.

\begin{tabular}{|c|c|c|c|c|c|c|}
\hline \multirow[b]{2}{*}{ Beta RS } & \multicolumn{3}{|c|}{ Raw returns } & \multicolumn{3}{|c|}{ Carhart alphas } \\
\hline & Winner & Loser & W-L & Winner & Loser & W-L \\
\hline 1 & 0.0531 & 0.0143 & $\begin{array}{l}0.0388^{* * * *} \\
(3.19)\end{array}$ & 0.0587 & 0.0386 & $\begin{array}{l}0.0200^{* * * *} \\
(3.11)\end{array}$ \\
\hline 2 & 0.0328 & 0.0221 & $\begin{array}{l}0.0107 \\
(0.61)\end{array}$ & 0.0430 & 0.0433 & $\begin{array}{l}-0.0003 \\
(-0.03)\end{array}$ \\
\hline 3 & 0.0496 & 0.0096 & $\begin{array}{l}0.0400 * * * \\
(2.46)\end{array}$ & 0.0514 & 0.0412 & $\begin{array}{l}0.0102 * \\
(1.47)\end{array}$ \\
\hline 4 & 0.0177 & 0.0314 & $\begin{array}{l}-0.0231 \\
(-0.85)\end{array}$ & 0.0442 & 0.0409 & $\begin{array}{l}0.0033 \\
(0.47)\end{array}$ \\
\hline 5 & 0.0100 & 0.0348 & $\begin{array}{l}-0.0247^{* *} \\
(-1.94)\end{array}$ & 0.0373 & 0.0466 & $\begin{array}{l}-0.0093^{*} \\
(-1.62)\end{array}$ \\
\hline
\end{tabular}

B.

\begin{tabular}{|c|c|c|c|c|c|c|}
\hline \multirow[b]{2}{*}{1} & \multicolumn{3}{|c|}{ Raw returns } & \multicolumn{3}{|c|}{ Carhart alphas } \\
\hline & 0.0589 & 0.0183 & $\begin{array}{l}0.0407 * * * \\
(3.39)\end{array}$ & 0.0499 & 0.0490 & $\begin{array}{l}0.0009 \\
(0.13)\end{array}$ \\
\hline 2 & 0.0406 & 0.0124 & $\begin{array}{l}0.0281 * * * \\
(1.71)\end{array}$ & 0.0498 & 0.0384 & $\begin{array}{l}0.0114 * \\
(1.42)\end{array}$ \\
\hline 3 & 0.0265 & 0.0287 & $\begin{array}{l}-0.0022 \\
(-0.14)\end{array}$ & 0.0463 & 0.0413 & $\begin{array}{l}0.0050 \\
(0.66)\end{array}$ \\
\hline 4 & 0.0363 & 0.0249 & $\begin{array}{l}0.0114 \\
(0.76)\end{array}$ & 0.0052 & 0.0510 & $\begin{array}{l}0.0006 \\
(0.07)\end{array}$ \\
\hline 5 & 0.0112 & 0.0474 & $\begin{array}{l}-0.0362 * * * \\
(-2.97)\end{array}$ & 0.0449 & 0.0414 & $\begin{array}{l}0.0035 \\
(0.58)\end{array}$ \\
\hline
\end{tabular}

C.

\begin{tabular}{|c|c|c|c|c|c|c|}
\hline Idio $\mathrm{R}$ & \multicolumn{3}{|c|}{ Raw returns } & \multicolumn{3}{|c|}{ Carhart alphas } \\
\hline 1 & 0.0210 & 0.0257 & $\begin{array}{l}-0.0047 \\
(-0.37)\end{array}$ & 0.0428 & 0.0394 & $\begin{array}{l}0.0035 \\
(0.57)\end{array}$ \\
\hline 2 & 0.0480 & 0.0130 & $\begin{array}{l}0.0350 \text { ** } \\
(2.05)\end{array}$ & 0.0373 & 0.0472 & $\begin{array}{l}-0.0010 \\
(-1.16)\end{array}$ \\
\hline 3 & 0.0250 & 0.0267 & $\begin{array}{l}-0.0017 \\
(-0.10)\end{array}$ & 0.0454 & 0.0412 & $\begin{array}{l}0.0042 \\
(0.65)\end{array}$ \\
\hline 4 & 0.0251 & 0.0169 & $\begin{array}{l}0.0082 \\
(0.51)\end{array}$ & 0.0462 & 0.0363 & $\begin{array}{l}0.0099 * \\
(1.41)\end{array}$ \\
\hline 5 & 0.0287 & 0.0149 & $\begin{array}{l}0.0138 \\
(1.10)\end{array}$ & 0.0486 & 0.0437 & $\begin{array}{c}0.0049 \\
(0.78)\end{array}$ \\
\hline
\end{tabular}


TABLE 11. (Continued)

\begin{tabular}{|c|c|c|c|c|c|c|}
\hline \multirow[b]{2}{*}{ Idio RS } & \multicolumn{3}{|c|}{ Raw returns } & \multicolumn{3}{|c|}{ Carhart alphas } \\
\hline & Winner & Loser & W-L & Winner & Loser & W-L \\
\hline 1 & 0.0269 & 0.0271 & $\begin{array}{l}-0.0003 \\
(-0.02)\end{array}$ & 0.0398 & 0.0451 & $\begin{array}{l}-0.0052 \\
(-0.82)\end{array}$ \\
\hline 2 & 0.0338 & 0.0243 & $\begin{array}{l}0.0094 \\
(0.59)\end{array}$ & 0.0386 & 0.0532 & $\begin{array}{l}-0.0146^{* *} \\
(-1.63)\end{array}$ \\
\hline 3 & 0.0273 & 0.0278 & $\begin{array}{l}-0.0005 \\
(-0.03)\end{array}$ & 0.0416 & 0.0451 & $\begin{array}{l}-0.0036 \\
(-0.52)\end{array}$ \\
\hline 4 & 0.0267 & 0.0269 & $\begin{array}{l}-0.0002 \\
(-0.01)\end{array}$ & 0.0579 & 0.0299 & $\begin{array}{l}0.0280^{* * *} \\
(3.83)\end{array}$ \\
\hline 5 & 0.0347 & 0.0144 & $\begin{array}{l}0.0203^{* * *} \\
(1.70)\end{array}$ & 0.0516 & 0.0451 & $\begin{array}{l}0.0066 \\
(1.00)\end{array}$ \\
\hline
\end{tabular}

Note: This table presents the fund performance subsequent to risk shifting in terms of the systematic and the idiosyncratic risks. In Column 1, funds are ranked in ascending order to form 5 groups according to the magnitude of risk shifting. Panels A and B C and D report the results based on sorting by systematic risk idiosyncratic risk on a 6-6 and 7-5 basis, respectively. Funds are further sorted into the winner loser group if their performance is higher lower than the median performance of the family. The subsequent fund performance is calculated for each of the risk shifting groups and the corresponding winner and loser groups. The differences between the winner and loser groups are presented for each type of performance evaluation, with $t$ statistics in brackets. All results reported are in percentage values. ${ }^{* * *}, * *$ and $*$ indicate significance at the $1 \%, 5 \%$ and $10 \%$ level.

their underlying funds. Moreover, the results also find some evidence to support a close relation between the increase of cross-sectional idiosyncratic risks and the probability of funds in the dog families being promoted, i.e. $\Delta \Lambda_{i, t}^{\varepsilon} * D_{\text {Dog }}$ has a coefficient equal to 1.189 when mean returns are considered for ranking, and this increases to 1.264 and 1.260 when FF alphas or Carhart alphas are used. Dog families contain funds that are ranked in the bottom $10 \%$ of the segment and none of their members have top performance. Therefore, they are motivated to undertake various strategies to create stars. Despite this, the results in table 12 imply that dog families improve performance of a certain member by sacrificing the profits of others. In addition to funds' total risk, changes in cross-sectional idiosyncratic risk can also be a channel to improve performance. Thus, fund families may increase industrial concentration in the holdings of a certain fund and diversify the holdings of others to bet on the market.

However, we find only weak evidence to suggest such a strategy in 
TABLE 12. Aggregated family ranks analysis

\begin{tabular}{|c|c|c|c|c|}
\hline Odds ratio & Raw returns & CAPM alphas & FF alphas & Carhart alphas \\
\hline \multirow{2}{*}{$R_{i, t}^{\Delta \sigma}$} & $0.5822 * *$ & $0.8431 * *$ & $0.7888 * *$ & $0.6330 *$ \\
\hline & $(-2.01)$ & $(-2.14)$ & $(-2.33)$ & $(-1.72)$ \\
\hline \multirow[t]{2}{*}{$\Delta \Lambda_{i, t}^{\sigma} \cdot D_{\text {Star }}$} & $1.3513^{*}$ & $1.3000 *$ & $1.4059 *$ & $1.3211 *$ \\
\hline & $(1.64)$ & $(1.61)$ & $(1.72)$ & $(1.61)$ \\
\hline \multirow{2}{*}{$\Delta \Lambda_{i, t}^{\sigma} \cdot D_{D o g}$} & $4.1741 * * *$ & $2.3911 * *$ & $4.0054 * * *$ & $3.2246 * *$ \\
\hline & $(3.08)$ & $(2.01)$ & $(2.94)$ & $(2.52)$ \\
\hline \multirow{2}{*}{$\Delta \Lambda_{i, t}^{\sigma} \cdot D_{S t a r, D o g}$} & 0.8543 & 0.9465 & 0.8277 & 0.8465 \\
\hline & $(-0.91)$ & $(-0.32)$ & $(-1.04)$ & $(-0.92)$ \\
\hline \multirow[t]{2}{*}{$\Delta \Lambda_{i, t}^{\beta} \cdot D_{\text {Star }}$} & 1.0000 & 0.9999 & 0.9999 & 0.9999 \\
\hline & $(-0.06)$ & $(-0.54)$ & $(-0.70)$ & $(-0.82)$ \\
\hline \multirow[t]{2}{*}{$\Delta \Lambda_{i, t}^{\beta} \cdot D_{D o g}$} & 0.9999 & 0.9999 & 1.0000 & 0.9999 \\
\hline & $(-1.18)$ & $(-0.72)$ & $(-0.40)$ & $(-0.53)$ \\
\hline \multirow[t]{2}{*}{$\Delta \Lambda_{i, t}^{\beta} \cdot D_{\text {Star }, \text { Dog }}$} & 1.0000 & 1.0008 & 1.0000 & 1.0000 \\
\hline & $(0.87)$ & $(0.67)$ & $(0.17)$ & $(0.43)$ \\
\hline \multirow[t]{2}{*}{$\Delta \Lambda_{i, t}^{\varepsilon} \cdot D_{\text {Star }}$} & 1.0025 & 0.9859 & 0.9979 & 1.0208 \\
\hline & $(0.04)$ & $(-0.21)$ & $(-0.02)$ & $(0.28)$ \\
\hline \multirow[t]{2}{*}{$\Delta \Lambda_{i, t}^{\varepsilon} \cdot D_{D o g}$} & $1.1893 *$ & $1.1851^{*}$ & $1.2643 * * *$ & $1.2100 * *$ \\
\hline & (1.89) & $(1.86)$ & (2.64) & $(2.20)$ \\
\hline \multirow{2}{*}{$\Delta \Lambda_{i, t}^{\varepsilon} \cdot D_{\text {Star }, \text { Dog }}$} & 0.9145 & 0.9433 & 0.9844 & 0.9911 \\
\hline & $(-1.21)$ & $(-0.85)$ & $(-0.24)$ & $(-0.13)$ \\
\hline$\chi^{2}$ & 26.90 & 14.61 & 25.29 & 21.22 \\
\hline Obs. & 534 & 534 & 534 & 534 \\
\hline
\end{tabular}

Note: This table presents the odds ratios from the post-ranking performance analysis of model 2. Fund families are ranked according to performance changes of the underlying members. Fund performance is estimated by four evaluation measures: the raw total returns, the CAPM alphas, the Fama French alphas and the Carhart alphas. $\Delta \Lambda_{i, t}^{\sigma}, \Delta \Lambda_{i, t}^{\beta}$ and $\Delta \sigma_{i, t}^{\varepsilon}$ are the cross sectional risk difference on funds' total risk, the systematic risk and the idiosyncratic risk between the ranking and post-ranking period, respectively. $R_{i, t}^{\Delta \sigma}$ is the family rank that measures the level of risk shifting for individual funds within the family. $D_{\text {Star }}$ $D_{D o g}$ is equal to 10 when the family is a star dog family. $D_{\text {Star,Dog }}$ is equal to 1 if the family has both star and dog funds and 0 otherwise. The model is fitted by the ordinal logistic model. The $z$ statistics are shown in brackets. ${ }^{* * *}, * *$ and $*$ indicate significance at the $1 \%, 5 \%$ and $10 \%$ level.

the star families. For example, the coefficients on $\Delta \Lambda_{i, t}^{\sigma} * D_{\text {Star }}$ are in lower values, equalling to 1.351 when raw returns are used and 1.321 when Carhart alphas are used for measurement of the performance, and only significant at the $10 \%$ significance level. It is plausible that the star funds are already rewarded with increased cash inflows, which can also benefit other peer funds for their performance enhancement.

Table 12 also shows a significant relation between performance 
improvement and the shifting funds' idiosyncratic risk, which is consistent with previous results. But it seems to have lesser power in explaining the aggregated rank promotion compared with the contribution made by the changes in cross-sectional risk. Moreover, no conclusive evidence can be found that shifting of the systematic risk exposure is related to the increases in the aggregate performance ranks.

\section{Cross-fund subsidization in family tournament}

In this section, we examine the fund family's strategy of cross-fund subsidization. The above research documents that mid-year winners outperform the losers in the risk-adjusted returns by increasing their risk exposure, but the situation reverses when it turns to observed returns. The results argue that it might be due to managers' intention to signal the fund family about their superior skills in order to gain additional resource from the fund family. Gaspar et al. (2006) suggests an empirical method to test the strategy of family's cross-fund subsidization which can be considered as the major channel for the family to promote their favourite funds. To address the concerns regarding to the family favouritism as the reward of higher risk-adjusted returns, we modify their method to rank funds according to their Carhart alphas for each month. Funds ranked above the $25^{\text {th }}$ and $75^{\text {th }}$ percentile are formed as the Low and High value group, respectively. Two sets of High/Low value pairs are then constructed. In the actual pair, each of the funds in the High value group is matched with a fund within the same family but in the Low value group. In the second set of the High/Low value pairs, the matching pairs, each of the low value funds in the actual pairs is replaced by a random selected fund within the same ranking percentile as the original low value fund but from a different fund family. The return differences between the High and Low value funds for each pair then act as the dependant variable. The empirical model can be shown as following:

$$
R_{i, t}^{H}-R_{i, t}^{L}=\alpha_{i}+\beta_{i}^{(1)} D_{i, t}^{\text {Family }}+\beta_{i}^{(2)} D_{i, t}^{\text {Style }}+\varepsilon_{i, t}
$$

where $D_{i, t}^{\text {Family }}$ and $D_{i, t}^{\text {Style }}$ are the dummy variables that takes the value of 1 when funds within the pair belong to the same family or the same investment style, respectively. If the family does subsidise the mangers with superior skill, we expect that the same-family dummy is positively 
TABLE 13. Cross-fund subsidization

\begin{tabular}{|c|c|c|c|}
\hline \multicolumn{4}{|l|}{ A. $1^{\text {st }}$ half year } \\
\hline & Intercept & $D^{\text {Family }}$ & $D^{\text {Style }}$ \\
\hline Coeff. & $0.1027 * * *$ & $-0.0325^{* * *}$ & $0.0438 * * *$ \\
\hline t-Stat. & $(22.62)$ & $(-6.01)$ & $(7.85)$ \\
\hline Adjusted $R^{2}$ & 0.16 & & \\
\hline \multicolumn{4}{|l|}{ B. $2^{\text {nd }}$ half year } \\
\hline & Intercept & $D^{\text {Family }}$ & $D^{\text {Style }}$ \\
\hline Coeff. & $0.0082 * * *$ & $0.0082 * *$ & $-0.0090 * *$ \\
\hline t-Stat. & $(2.20)$ & (1.99) & $(-2.00)$ \\
\hline Adjusted $R^{2}$ & 0.09 & & \\
\hline \multicolumn{4}{|l|}{ C. Monthly } \\
\hline & Intercept & $D^{\text {Family }}$ & $D^{\text {Style }}$ \\
\hline \multirow[t]{2}{*}{ Feb. } & $0.1137 * * *$ & $-0.0170 *$ & $0.0515 * * *$ \\
\hline & $(14.85)$ & $(-1.87)$ & $(5.58)$ \\
\hline \multirow[t]{2}{*}{ Mar. } & $0.1721 * * *$ & $-0.1437 * * *$ & $0.0279 *$ \\
\hline & $(15.67)$ & $(-10.57)$ & $(1.93)$ \\
\hline \multirow[t]{2}{*}{ Apr. } & $0.0405^{* * *}$ & -0.0184 & $0.0520 * * *$ \\
\hline & $(3.41)$ & $(-1.29)$ & $(3.52)$ \\
\hline \multirow[t]{2}{*}{ May } & $0.0621 * * *$ & $0.0341 * * *$ & $0.0450 * * *$ \\
\hline & $(9.94)$ & $(4.69)$ & $(6.05)$ \\
\hline \multirow[t]{2}{*}{ Jun. } & 0.0068 & $0.0557 * * *$ & $-0.0270 * * *$ \\
\hline & $(0.97)$ & $(6.84)$ & $(-3.27)$ \\
\hline \multirow[t]{2}{*}{ Jul. } & $-0.1491 * * *$ & $0.1536^{* * *}$ & $-0.0462 * * *$ \\
\hline & $(-16.30)$ & (13.78) & $(-4.04)$ \\
\hline \multirow[t]{2}{*}{ Aug. } & $-0.0749 * * *$ & -0.0161 & $0.0215^{* *}$ \\
\hline & $(-9.94)$ & $(-1.74)$ & $(2.26)$ \\
\hline \multirow[t]{2}{*}{ Sep. } & $0.2225^{* * * *}$ & $-0.2045^{* * *}$ & $0.0224 *$ \\
\hline & $(19.29)$ & $(-15.23)$ & $(1.64)$ \\
\hline \multirow[t]{2}{*}{ Oct. } & $-0.0140 *$ & $0.0315^{* * *}$ & $0.0230 * *$ \\
\hline & $(-1.78)$ & $(3.29)$ & $(2.31)$ \\
\hline \multirow[t]{2}{*}{ Nov. } & $-0.0184 * *$ & $0.0268 * * *$ & $-0.0359^{* * *}$ \\
\hline & $(-2.52)$ & $(3.29)$ & $(-4.40)$ \\
\hline \multirow[t]{2}{*}{ Dec. } & $0.0137 *$ & $0.0368 * * *$ & 0.0107 \\
\hline & (1.64) & $(3.61)$ & $(0.98)$ \\
\hline
\end{tabular}


TABLE 13. (Continued)

Note: This table presents the regression results from the test of cross-fund subsidization. For each month, we rank all the funds in ascending orders according to their Carhart alphas, and funds within the $25^{\text {th }}$ percentile $75^{\text {th }}$ percentile are formed to be the Low High value fund groups. The comparison peer group is all the funds in the same style. We then construct two sets of High/Low value pairs, namely, the actual pair and the matching pair. In the actual pair, each of the funds in the High value group is matched with a fund of the same family but in the Low value group. In the matching pair, each of the Low value funds in the actual pair is substituted with a fund taken from the same ranking percentile but within a different fund family. The return difference is then computed in the month following the ranking month. is the dummy variable which equals to 1 when the paired funds are in the same fund family. is the same style dummy that takes a value of 1 when the paired funds are within the same investment style. Panel A reports the results when we only consider the subsidization in the first half of the year while Panel B reports the results from the second half of the year. In Panel $\mathrm{C}$ we report the results from the monthly regression. Funds' daily returns from 3 UK IMA segments, UK All Companies, UK Equity Income and UK Small Companies, are examined for the sample years between 2001 and 2010. ${ }^{* *}, * *$ and $*$ indicate significance at the $1 \%, 5 \%$ and $10 \%$ level.

related with the return differences.

The results from $\mathrm{Eq}(5)$ are reported in table 13. It is suggested that fund family conduct significant cross-fund subsidization by shifting performance from high alpha funds to low alpha funds after the mid-year. For example, in Panel A the coefficient of the family dummy suggests that the return difference between the High/Low value funds of the same family is on average $0.82 \%$ higher than funds in matching pairs. However, opposite results are found when turning to the first half of the year in Panel A. In Panel C we further examine the cross-fund subsidization on a monthly basis. The results suggest that the family subsidization is more pronounced in the second half of the year when most of the coefficients of the same-family dummy is positive and significant from 0 .

The above findings support the view regarding the motivation of mangers' risk taking in the family tournament. Specifically, funds with high risk-adjusted returns gain benefits through the cross-fund subsidization which can drive managers' intention of active trading. The results also indicate that the fund family consider mangers' skill as the major criteria in judging which fund to be promoted. 


\section{Conclusions}

This research analyses the risk taking behaviour in fund family tournaments, and the performance consequences. Using the data from UK unit trusts, our research documents a significant risk taking behaviour in the family tournaments. The half-year winning funds in the family are likely to take more risks than their peers in the same family. On the other hand, winning managers would consider adopting similar risk taking strategies as the losers, since they have competitive advantages over the losers, such as more capital injection and family favouritism. This paper also analyses that how risk shifting is related to different incentive. By classifying the sampled years into bear and bull market condition, the results suggest a positive relation better risk taking and previous performance in the bear market when mid-year losers are more concerned about their jobs rather than compensation. And such a correlation is more pronounced than the situation in bull market when compensation incentive is dominant.

The results from the performance consequences of risk shifting show a strong relation between risk taking and performance changes. Regarding to the observed returns, they are consistent with the previous research in which increasing risk is accompanied with performance drop. But when turning to the risk-adjusted performance, risk shifting is positively correlated to funds' performance. Given that the half-year winners will increase their taking of systematic risk, the deterioration in funds' observed returns seems due to the mean reversion of high value equities in portfolio holdings. When risk-adjusted performance is considered, the winning funds outperform the losing ones in the post-ranking period. It is argued this is due to managers' intention to show off their skills in order to gain further subsidization from the fund family. The empirical results from the test of families' cross-fund subsidization support this view. In addition, no evidence is found that the increasing of the systematic risk or the idiosyncratic risk can lead to a strong performance improvement.

The analysis shows that the families that have extremely poor performing funds in their groups would manage to promote segment ranks of most of their underlying funds by increasing the cross-sectional volatility in both total and idiosyncratic risks. This implies that the fund family may sacrifice the profits of certain members to benefit the others, given the disproportionate responses in cash inflows and the spillover effect. This research thus provides empirical evidence on effects of 
family tournaments and performance shifting. In general, we find significant results to support the notion that risk taking in family tournaments can be viewed as an indication of managers' superior ability.

Accepted by: Prof. P. Theodossiou, Editor-in-Chief, February 2014

\section{References}

Ang, A., Hodrick, R. J., Xing, Y. and Zhang, X. 2006. The cross-section of volatility and expected returns. The Journal of Finance 61:259-299.

Brown, K. C., Harlow, W. V. and Starks, L. T. 1996. Of tournaments and temptations: An analysis of managerial incentives in the mutual fund industry. The Journal of Finance 51:85-110.

Carhart, M. M. 1997. On persistence in mutual fund performance. The Journal of Finance 52: 57-82.

Chevalier, J. and Ellison, G. 1997. Risk taking by mutual funds as a response to incentives. Journal of Political Economy 105:1167-1200.

Cuthbertson, K.; Nitzsche, D.; and O'Sullivan, N. 2008. UK mutual fund performance: Skill or luck? Journal of Empirical Finance 15:613-634.

Elton, E. J.; Gruber, M. J.; and Blake, C. R. 2003. Incentive fees and mutual funds. The Journal of Finance 58:779-804.

Evan, R. 2009. Does Alpha Really Matter? Evidence from Mutual Fund Incubation, Termination and Manager Change. Working paper, University of Virginia.

Faff, R.W.; Gharghori, P.; Ip, B.H.I;. and Nguyen, A. 2012. Return-based style analysis in Australian funds. Multinational Finance Journal 16:155-188.

Fama, E. F.; and French, K. R. 1993. Common risk factors in the returns on stocks and bonds. Journal of Financial Economics 33:3-56.

Gaspar, J.-M..; Massa, M.; and Matos, P. 2006. Favoritism in mutual fund families? Evidence on strategic cross-fund subsidization. The Journal of Finance 61:73-104.

Goetzmann, W.; Ingersoll, J.; Spiegel, M.; and Welch, I. 2007. Portfolio performance manipulation and manipulation-proof performance measures. Review of Financial Studies 20: 1503-1546.

Guedj, I., and Papastaikoudi, J. 2003. Can mutual fund families affect the performance of their funds? Working paper, Analysis Research Planning Corporation.

Huang, J.; Sialm, C.; and Zhang, H. 2011. Risk shifting and mutual fund performance. Review of Financial Studies 24:2575-2616.

Jain, P. C., and Wu, J. S. 2000. Truth in mutual fund advertising: Evidence on future performance and fund flows. The Journal of Finance 55:937-958. 
Jans, R., and Otten, R. 2008. Tournaments in the UK mutual fund industry. Managerial Finance 34:786-798.

Jensen, M. C. 1968. The performance of mutual funds in the period 1945-1964. The Journal of Finance 23:389-416.

Kacperczyk, M.,; Sialm, C.; and Zheng, L. U. 2005. On the industry concentration of actively managed equity mutual funds. The Journal of Finance 60:1983-2011.

Kempf, A., and Ruenzi, S. 2008. Tournaments in mutual-fund families. Review of Financial Studies 21:1013-1036.

Kempf, A.; Ruenzi, S.; and Thiele, T. 2009. Employment risk, compensation incentives, and managerial risk taking: Evidence from the mutual fund industry. Journal of Financial Economics 92:92-108.

Koski, J. L., and Pontiff, J. 1999. How are derivatives used? Evidence from the mutual fund industry. The Journal of Finance 54:791-816.

Lakonishok, J.; Shleifer, A.; Thaler, R.; and Vishny, R. 1991. Window dressing by pension fund managers. NBER Working paper No. 3617. Cambridge, Mass.: National Bureau of Economic Research.

Mas-Colell, A.; Whinston, M. D.; and Green, J. R. 1995. Microeconomic theory. New York: Oxford University Press.

Massa, M. 2003. How do family strategies affect fund performance? When performance-maximization is not the only game in town. Journal of Financial Economics 67:249-304.

Nanda, V.; Wang, Z. J.; and Zheng, L. 2004. Family values and the star phenomenon: Strategies of mutual fund families. Review of Financial Studies 17:667-698.

Rees, A. 1992. The tournament as a model for executive compensation. Journal of Post Keynesian Economics 14:567-571.

Schwarz, C. G. 2012. Mutual fund tournaments: The sorting bias and new evidence. Review of Financial Studies 25:913-936.

Sirri, E. R., and Tufano, P. 1998. Costly search and mutual fund flows. The Journal of Finance 53:1589-1622.

Taylor, J. 2003. Risk-taking behaviour in mutual fund tournaments. Journal of Economic Behavior \& Organization 50:373-383. 